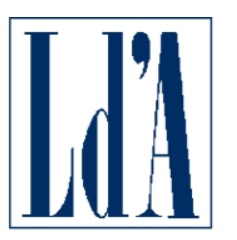

CENTRO STUDI LUCA D'AGLIANO

WWW.DAGLIANO.UNIMI.IT

CENTRO STUDI LUCA D'AGLIANO

DEVELOPMENT STUDIES WORKING PAPERS

N. 424

January 2017

Value Added in Motion: Determinants of Value Added Location within the EU

Lionel Fontagné*

Gianluca Santoni**

* PSE (Paris 1) and CEPII

$* *$ CEPII 


\title{
VALUE AdDED IN MOTION: DETERMINANTS OF VALUE ADDED LOCATION WITHIN THE EU*
}

\author{
Lionel Fontagné $^{\dagger} \&$ Gianluca Santoni ${ }^{\ddagger}$
}

\begin{abstract}
In this paper we approach the determinants of value added location across European countries, from the recent developments to the 2035 horizon. In the first part of the paper, using detailed trade data, we show how competitiveness, demand and export composition have shaped the market shares of European countries, hence the location of production in Europe. Variance and covariance analysis point to the specificity of two countries: the overall market share development seems to be significantly affected by aggregate demand conditions in Germany and Italy. We then turn to trade in value added and observe that bigger countries tend to report a higher share of domestic value added because they can count on more efficient national value chains or a higher diversity of goods upstream. Interestingly, such evidence does not apply to Germany, or Poland, which exhibit a more dynamic insertion in international value chains. In the second part of the paper, we present the main prospects for the allocation of labour (i.e. migration), value added and the macro-economic effects of energy prices across European countries up to year 2035. The projections presented in the paper aim to summarize the main results obtained by other researchers within the "Value Added in Motion (VAM)" project.
\end{abstract}

JEL Classification: F10, F14, F40, C43

Key Words: $\quad$ Export competitiveness, trade performance, trade patterns after the global crisis

* This report is prepared within the "Value Added in Motion (VAM)" project funded by the Enel Foundation. We thank Marzio Domenico Galeotti and Giorgio Barba-Navaretti for comments on an earlier draft of this version.

† PSE (Paris 1) and CEPII. Email: lionel.fontagne@univ-paris1.fr

¥ CEPII. Email: gianluca.santoni@cepii.fr 


\section{INTRODUCTION}

Trade has been an important source of economic growth for many countries. Notwithstanding, during the past two decades global economic environment has changed substantially, notably due to: the emergence of new competitors as well as the increasing fragmentation of production. Decrease in trade costs along with more efficient communication technologies and coordinated trade policies, in fact, increase the scope for sharing production processes across countries (Hoekman 2014). Those changes represent a key shift from the 20th century paradigm, when economies had to rely mostly on domestic supply chain as determinant of their external competitiveness. Given the current global context, countries need to strengthen their supply-side capacity and to optimally position themselves in the global trade and production network in order to compete successfully. From a policy perspective, then, it is crucial to understand how each country performs relative to competitors.

Concluding that a country is doing better internationally than another just because its exports are growing faster is overly simplified. Even focusing on relative performance, i.e. market share growth, may induce misinterpretation. Two countries may have a very similar set of exporting firms, but one could perform better in the short-medium term only because it has a more favourable export structure, both in terms of geographical and sectoral composition. Export dynamics, in fact, is driven by two main factors: compositional components and pure performance effects, meaning competiveness stricto sensu.

In what follows, we analyze European trade performance using the methodology proposed by Gaulier et al. (2013): whose main results are publicly available from the Measuring Export Competitiveness database (MEC) ${ }^{1}$. More in detail, export growth is analyzed using an econometric Constant Market Share (CMS) accounting technique, based on weighted OLS regression. The advantage of the econometric decomposition is that it overcomes the main drawbacks of the traditional algebraic CMS approach ${ }^{2}$ and allows the identification of the independent contribution, to overall export market shares change, due to product and market specialization compared to that due to exporter-specific factors (country competitiveness). By using such decomposition it is possible to distinguish between "pull" and "push" factors in export market shares growth.

Recent economic literature on firm heterogeneity (Melitz 2003; Chaney, 2008, Melitz and Ottaviano 2008) shows that there is a "performance" cut-off associated to each market; where the cut-off represents the minimum level of productivity that a firm needs to reach in order to compete successfully. Ottaviano et al. (2009) and Corcos et al. (2012) show that the "cut-off" depends on the demand and the remoteness of the market, but also on a specific term which identifies the determinants of a country's capability to generate high productive (low-cost) firms. This term is meant to capture exogenous determinants of a country firms' productivity distribution. According to their model, the key determinants of supply-side performance are: fixed costs (determined by trade policy, regulation or exporter-specific trade costs); inputs costs (capital and labour unit costs, availability of skilled human capital); and technology (structural and macro-economic determinants). As suggested by Gaulier et al. (2013) within this theoretical framework the pure performance effects factor may be seen an indicator of micro and macroeconomic constraints of supply-side competitiveness.

International fragmentation of production is not a new idea. Following Baldwin (2006, 2012) a major production "unbundling" happened already during the 1980s, when the production process was divided

1 The MEC database is updated twice a year and publicly available at http://mec.worldbank.org/

2 In particular, the competitiveness effect is estimated rather than computed as a residual the result is that product and market structure effects are orthogonal. 
both across countries (off-shoring) and production phases (out-sourcing) ${ }^{3}$. Indeed, it has become increasingly relevant in the last two decades: from 1990 to 2010 the import content of exports rose from 20 to $40 \%$, with an expected further increase to $60 \%$ by 2030 (Lamy 2013). This implies that supply-side performance is significantly influenced by a country involvement in complex international production chains. From a policy perspective, then, country fitness in Global Value Chains (GVC) is crucial to spur exports as well as domestic value added (Taglioni and Winkler 2014).

Involvement in GVCs, in fact, implies opportunities as well as risks. On one hand, it may allow countries to overcome their (national) comparative advantage. On the other hand, it may also expose to some risks, notably those related to imported crisis through trade (Escaith, Lindinberg and Miroudot, 2010) or diffusion of shocks - as for the earthquake that hit Japan in 2011 and whose effect spreads over other Asian countries (Fujita, 2013).

Understanding trade and value added exchange patterns in the current economic environment is extremely important in order to design effective policies, but being able to anticipate medium or long run growth scenarios is crucial. The future geography of production, migration and energy and its consequences for the largest European countries is described in a companion paper (Fontagné and Fouré, 2015). Taking a 2035 horizon, they examine how world trade patterns will be shaped by the changing comparative advantages, demand, and capabilities of different regions and its implications in terms of location of value added.

Finally, Fontagné et al. (2015) focus on energy prices - on their evolution in the next 20 years and the effect on economic projections on different price evolution patterns. Thanks to the combination of macroeconomic trends taken from a growth model (MaGE) with a Computable General Equilibrium model (MIRAGE-e, a sectoral decomposition of growth and factor allocation, as well as country specialization and world trade patterns) can be described for alternative scenarios, in a regional perspective.

The rest of this paper is organized as follows. Section 2 studies the pattern of export growth determinant for the largest European economies, while Section 3 analyses the degree of participation to Global Value Chains and the last Section concludes.

\section{EU EXPORT PERFORMANCE}

In this section we focus on the export performance of European countries through the decomposition of market shares growth over the period 2005-2014. Using the "Measuring Export Competitiveness" (MEC) database developed by Gaulier et al. (2013) we analyze changes in world market shares adjusted by compositional effects ${ }^{4}$. The methodology disentangles compositional effects due to market orientation and industrial specialization from country-specific supply shocks, and their relative contribution to market share changes.

As mentioned before, looking at the evolution of market shares alone may result in a flawed picture of country external competitiveness. The emergence of new competitors, in fact, has induced a generalized loss in market shares for most of the developed countries. Noteworthy market shares may contract even if

3 This was the second large production "unbundling", the first one occurs from 1850-1914 and from the 1960s onwards, with the separation between production and consumption.

4 The database provides internationally comparable quarterly information for 228 countries and territories. It is based on monthly data available since 2005 at the HS 6-digit level (1996 classification) from Trade Map of the International Trade Centre (ITC). 
exports are expanding, providing that they are growing at a slower pace than world average. On the opposite, an economy may improve its global market position only because it is serving the most dynamic importers or supplying most demanded goods. Given this context, a key question, for its policy implication, would be: how much such (gains) losses are due to export composition, in terms of markets and sectors, and how much are related to country competitiveness?

In order to disentangle the relative contribution of sectoral and geographical components on market shares changes, Gaulier et al. (2013) start from a world trade matrix of exports at HS-6 digit level of disaggregation. Trade flows are recorded quarterly to better control for the timing of any shocks (such as the global trade collapse of 2008q3-2009q1) and the analysis focuses on growth rates to control for any time-invariant export determinant ${ }^{5}$. Export growth rates decomposition is carried out using an econometric shift-share analysis, where in each quarter the growth of exports in product $k$ from country $i$ to destination $j$ is regressed on exporter, product and destination fixed effects. The contribution of each dimension is identified by the estimated fixed effects ${ }^{6}$.

- $\quad$ Fixed Effect i: exporter specific factors

- Fixed Effect j: destination market factors

- Fixed Effect k: exporter industrial specialization

From the above decomposition, we derive the "adjusted market shares" a measure of the contribution of exporter specific factors to market share change: which we use as a proxy of changes in supply in the exporting country. Thanks to the aforementioned technique we are able to fully characterize export performance into three components: an indicator of external competitiveness (i.e. progress in market shares not related to product or market distribution) and two indexes on the relative contribution of geography (destination markets) and sector composition of exports.

Table 1 shows the average year-on-year change for each indicator over the whole data period, aggregated by major world regions. On average, over the nine years covered by the data set, export performance, stripped of the effects of geographical specialization and product mix orientation, was strongest for most of the developing world, especially in South-East Asian countries: China (10.4\%) and India (9.7\%). Considering a world (estimation sample) export growth rate of roughly $6.2 \%$ the result is a substantial increase in market share for those countries: of about 4.3 and $3.5 \%$ respectively. A similar trend, with high export growth and market share gains, is shared by most of the other developing countries.

Moreover such performance was not driven by specialization but rather by the domestic performance factors, which we will refer to as "adjusted market shares”. Turning to compositional effects, South Asia (SAR), and Sub-Saharan Africa (AFR) have had the strongest positive impact from their choice of destination markets. In contrast, sectoral specialization has served well Sub-Saharan Africa (AFR), the Middle-East and North Africa (MENA) region and Eastern Europe and Central Asia (ECA).

Regarding country competitiveness effects (market share growth excluding composition effects), China reports a positive contribution of about $7.5 \%$ per year that outperforms almost all other countries. Interestingly, this remarkable performance is partially offset by a negative sectoral composition $-3 \%$, suggesting a specialization in products and sectors of relatively low growth. Looking at the geographical composition this was, on average, almost neutral for the BRICS as aggregate, but highly heterogeneous among them: ranging from the $-0.2 \%$ of China to the $+1.2 \%$ of Brazil.

5 Note that Changes are measured in log first differences, since these preserve additive properties. 6 See Appendix A for a detailed discussion of the econometric shift share approach. 
As a consequence of the emergence of new competitors, most of the G3 countries have lost market shares, between 2006 and 2014, on average $-1.8 \%$ annually. The losses were particularly large in Japan, UK and EU28, possibly due to relocation of production stages towards more cost-efficient locations. Euro Area share of global exports dropped by $2 \%$, during the same period, despite an annual export growth of $4.3 \%$. In terms of composition effects the geographical specialization helped US (0.6\%) and Japan (1.5\%), while dampened EU export growth, with an annual negative contribution of $-0.9 \%$. Since the above figures are weighted means of individual country performances, they average out country-specific developments. For this reason it is useful to look at the developments in individual countries.

Table 1: Decomposition of export growth, 2006q1 - 2014q3 (\%)

\begin{tabular}{lccccccc}
\hline & $\begin{array}{c}\text { Export } \\
\text { growth }\end{array}$ & $\begin{array}{c}\text { Export market } \\
\text { share change }\end{array}$ & \multicolumn{2}{c}{ Composition effects } & \multicolumn{4}{c}{ Competitiveness } \\
Geographical & Sectoral & Values & Price & Volumes \\
\hline G-3 & 4.4 & -1.8 & -0.2 & 0.0 & -1.6 & -0.5 & -1.2 \\
\hline USA & 5.9 & -0.3 & 0.6 & 0.6 & -1.5 & 0.0 & -1.4 \\
Japan & 2.2 & -4.0 & 1.5 & -0.7 & -4.8 & -0.5 & -4.3 \\
EU-28: & 4.4 & -1.8 & -0.8 & 0.0 & -1.0 & -0.6 & -0.4 \\
EA17: & 4.3 & -1.9 & -0.8 & 0.0 & -1.1 & -0.6 & -0.5 \\
$\quad$ France & 3.0 & -3.2 & -0.8 & 0.7 & -3.1 & -0.7 & -2.4 \\
$\quad$ Germany & 4.5 & -1.7 & -0.5 & -0.2 & -1.0 & -0.7 & -0.4 \\
$\quad$ Italy & 4.0 & -2.2 & -0.5 & -0.6 & -1.1 & -0.4 & -0.7 \\
UK & 2.3 & -3.9 & -0.9 & 0.4 & -3.3 & -1.1 & -2.2 \\
\hline BRICS & 9.6 & 3.4 & 0.0 & -1.5 & 4.9 & 1.2 & 3.7 \\
\hline Brazil & 7.0 & 0.8 & 1.2 & 1.2 & -1.7 & 0.9 & -2.6 \\
Russia & 7.1 & 0.9 & 0.0 & 1.9 & -1.0 & 0.8 & -1.8 \\
India & 9.7 & 3.5 & 0.8 & 0.6 & 2.1 & -0.7 & 2.8 \\
China & 10.4 & 4.3 & -0.2 & -3.0 & 7.5 & 1.6 & 6.0 \\
South Africa & 7.5 & 1.4 & 0.9 & 1.4 & -0.9 & 0.0 & -0.9 \\
\hline AFR & 7.2 & 1.0 & 0.5 & 1.6 & -1.2 & 0.1 & -1.3 \\
EAP & 9.7 & 3.5 & 0.1 & -2.1 & 5.5 & 1.1 & 4.3 \\
SAR & 9.3 & 3.1 & 0.5 & -0.2 & 2.9 & -0.5 & 3.4 \\
ECA & 7.7 & 1.5 & 0.0 & 0.8 & 0.7 & 0.5 & 0.2 \\
MENA & 6.0 & -0.2 & 0.0 & 2.1 & -2.3 & 0.3 & -2.5 \\
\hline
\end{tabular}

Note: in order to preserve additivity, the values are expressed as averages of year-on-year log changes. Delta log approximates almost exactly percentage growth rates for relatively small changes (e.g. $\ln (1+5 \%)=0.0488)$. Source: Measuring Export Competitiveness database (World Bank, International Trade Center \& Bank of France).

In Table 2 we analyze the export performance of a sub-set of European countries in two periods: 2006q1$2008 \mathrm{q} 3$ and 2011q3-2014q3 $3^{7}$. Export performance in the euro area was mostly negative in terms of market shares and this is to be explained to a large extent by competiveness. The negative performance in the second period is associated with both the financial crisis and the euro-debt crisis. However, results for the two sub-periods show that by and large the crisis did not serve as a structural break but rather as a

7 We focus on the first eight countries in terms of EU28 GDP; note that the selected sample account for 83\% of the overall economic activity (GDP) in 2013. 
magnification of pre-existing trends. Only Poland (+2.7\%) managed to keep a positive export performance in the aftermath of the 2008 financial crisis; even in presence of a negative price effect (not surprisingly, price development follows a common trajectory for all EU countries). The euro-debt crisis was particularly detrimental for those countries whose exports are concentrated towards Europe. This is clearly the case for all countries reported in Table 2: the contribution of geographical specialization moved for all of them from positive to negative territory; Netherlands and Poland $(-1.9 \%)$, Spain $(-1.8 \%)$ were the economies suffering more for the fall in demand induced by the sovereign debt crisis.

Table 2: Decomposition of export growth, EU28 major countries (\%)

\begin{tabular}{|c|c|c|c|c|c|c|c|}
\hline & \multirow{2}{*}{$\begin{array}{l}\text { Export } \\
\text { growth }\end{array}$} & \multirow{2}{*}{$\begin{array}{l}\text { Export market } \\
\text { share change }\end{array}$} & \multicolumn{2}{|c|}{ Composition effects } & \multicolumn{3}{|c|}{ Competitiveness } \\
\hline & & & Geographical & Sectoral & Values & Price & Volumes \\
\hline \multicolumn{8}{|c|}{ Pre-Crisis (2006q1-2008q3) } \\
\hline EU28 & 14.2 & -0.9 & 1.2 & -1.3 & -0.9 & 0.0 & -0.9 \\
\hline France & 12.3 & -2.8 & 0.7 & -0.9 & -2.6 & -0.3 & -2.3 \\
\hline Germany & 14.7 & -0.5 & 1.4 & -1.5 & -0.4 & 0.2 & -0.6 \\
\hline Italy & 14.5 & -0.7 & 1.5 & -2.5 & 0.4 & 1.1 & -0.8 \\
\hline Netherlands & 18.1 & 2.9 & 0.9 & 0.0 & 2.0 & 0.2 & 1.8 \\
\hline Poland & 23.8 & 8.7 & 3.1 & -1.6 & 7.2 & 2.9 & 4.4 \\
\hline Spain & 13.5 & -1.7 & 0.8 & -1.5 & -1.0 & -0.1 & -1.0 \\
\hline Sweden & 12.7 & -2.4 & 1.2 & -0.8 & -2.8 & -1.4 & -1.4 \\
\hline United Kingdom & 9.0 & -6.1 & 0.4 & -0.2 & -6.3 & -1.9 & -4.4 \\
\hline \multicolumn{8}{|c|}{ Post Crisis (2011q3-2014q3) } \\
\hline EU28 & 2.1 & -0.9 & -1.3 & 0.7 & -0.3 & -0.2 & -0.1 \\
\hline France & 1.1 & -1.9 & -1.2 & 1.7 & -2.5 & -0.3 & -2.2 \\
\hline Germany & 2.5 & -0.5 & -1.1 & 0.8 & -0.2 & 0.1 & -0.3 \\
\hline Italy & 2.3 & -0.8 & -1.1 & 0.7 & -0.4 & -0.1 & -0.3 \\
\hline Netherlands & 1.8 & -1.2 & -1.9 & 0.6 & 0.1 & -0.2 & 0.3 \\
\hline Poland & 5.8 & 2.7 & -1.9 & -0.5 & 5.2 & -0.6 & 5.7 \\
\hline Spain & 2.9 & -0.1 & -1.8 & 0.9 & 0.8 & -1.0 & 1.7 \\
\hline Sweden & -0.6 & -3.7 & -0.9 & 0.2 & -3.0 & -0.3 & -2.7 \\
\hline United Kingdom & 1.6 & -1.5 & -1.0 & 0.5 & -1.0 & 0.0 & -1.0 \\
\hline
\end{tabular}


Among the composition effects, it is worth mentioning the different contributions of sectoral effects across European countries. While sectoral effects were largely neutral for Germany and Italy since 2009, these were generally positive for France, partially offsetting the negative geographical effect associated with the euro-debt crisis.

Figure 1 reports the country specific decomposition in both values and volume terms. Focusing on the latter, it emerges a great deal of heterogeneity across countries, notably in the sectoral component. On average both Germany and Italy report a negative contribution (in volumes) of the sectoral effect, which reveals a significant cyclicality (i.e. co-movement with export growth). For France, instead, the sectoral component appears to be less sensible to the business cycle and stably positive over the whole period. Such difference may be related to a different sectoral specialization. French export basket strength in nondurable, consumption and luxury goods (agri-food industry, pharmaceuticals and cosmetics, high end apparel and leather products) served the country well during the trade collapse and offset the greater fall in demand of durable goods, such as investment and automotive products (where Germany and Italy are more specialized).

\section{Figure 1: Export performance decomposition}

France, values

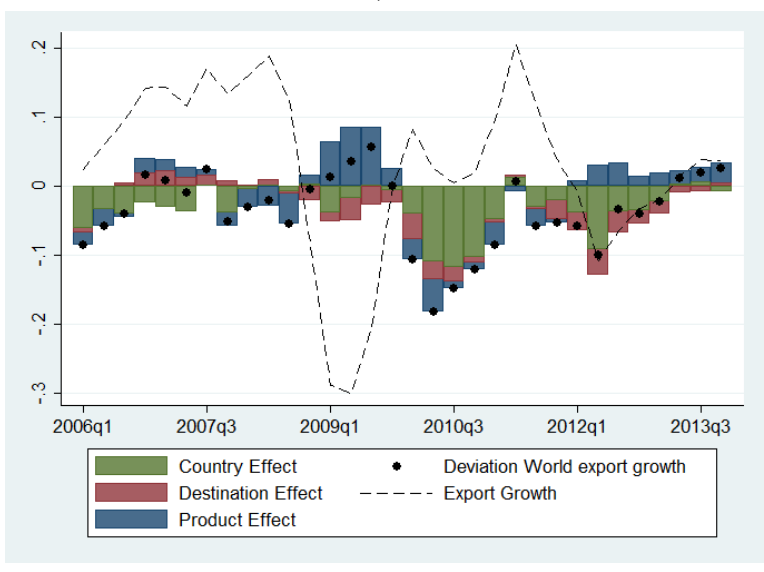

Germany, values

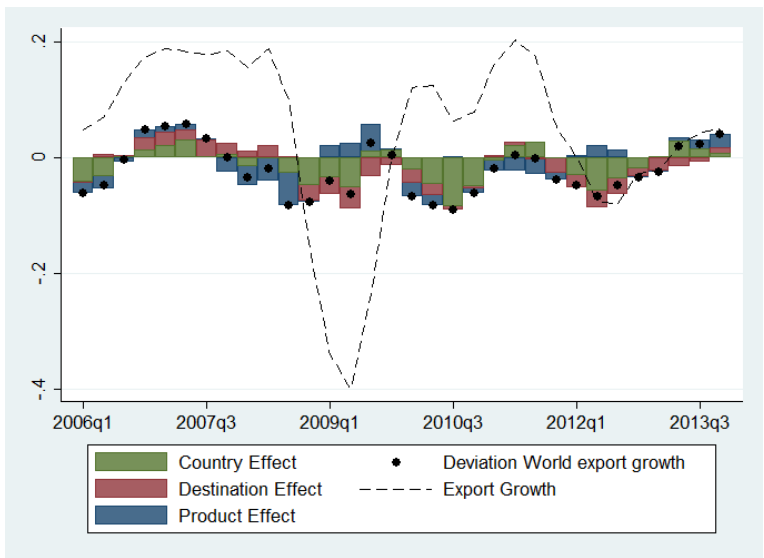

France, volumes

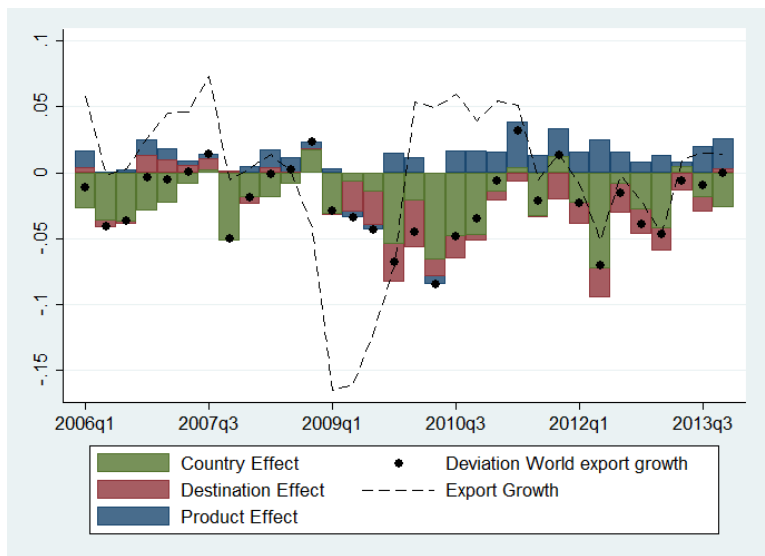

Germany, volumes

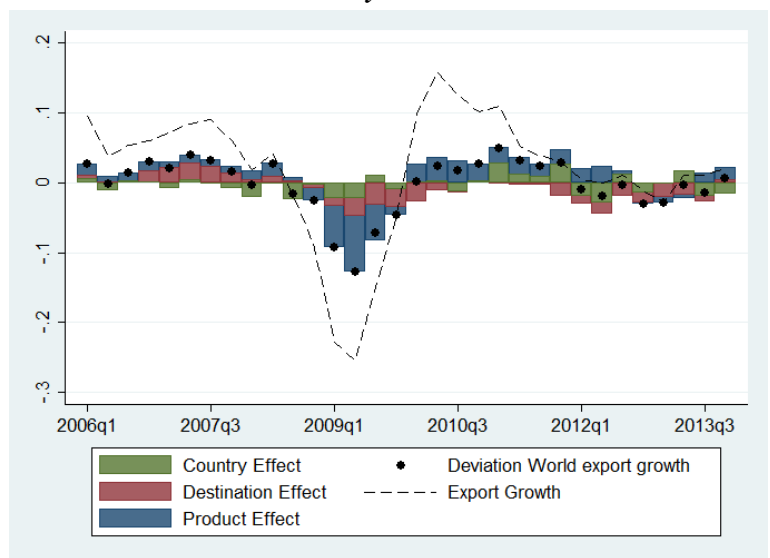



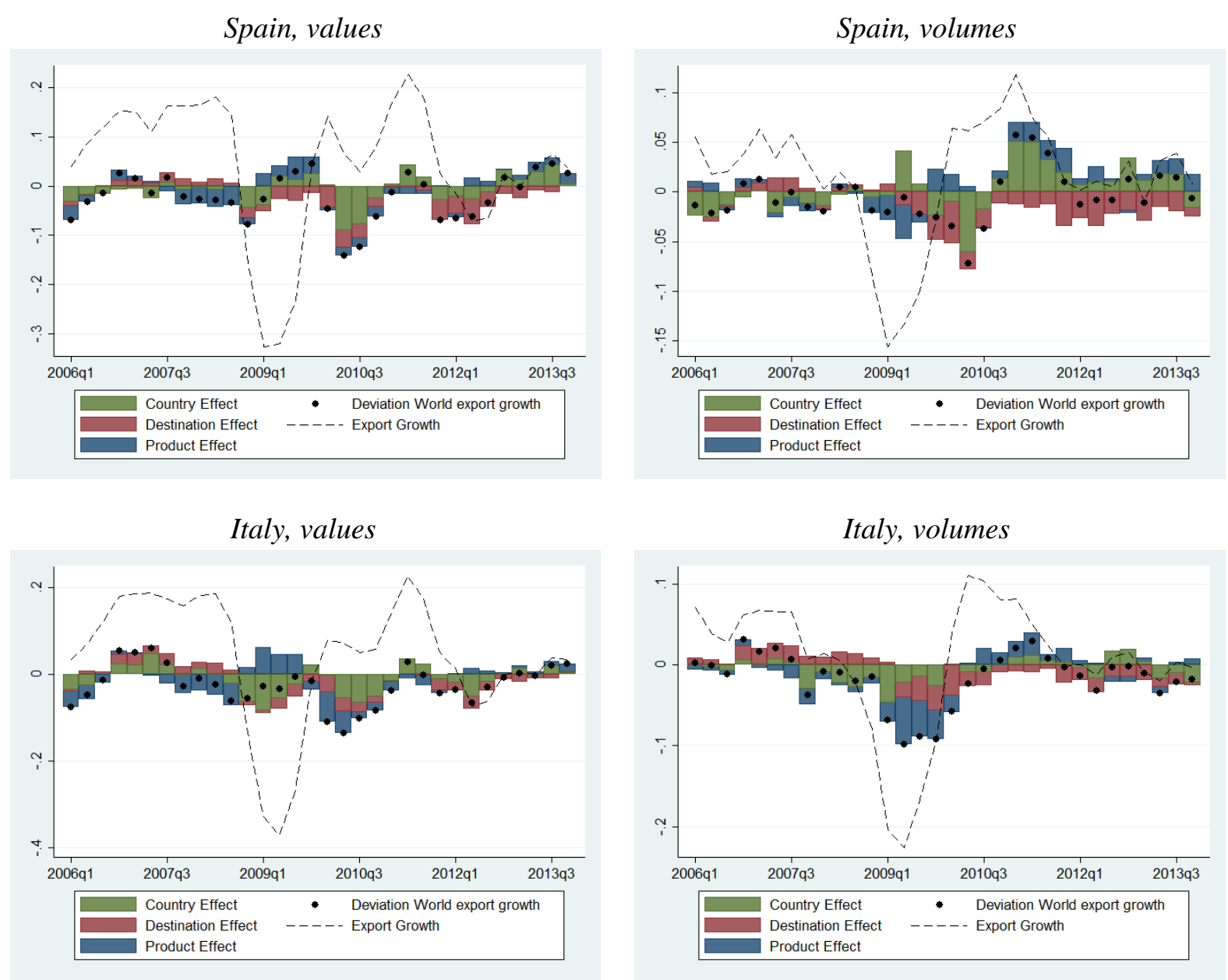

Note: Note: in order to preserve additivity, the values are expressed as averages of year-on-year log changes. Delta log approximates almost exactly percentage growth rates for relatively small changes (e.g. $\ln (1+5 \%)=0.0488)$. Source: Measuring Export Competitiveness database (World Bank, International Trade Center \& Bank of France).

This explanation is consistent with the empirical research on trade slump, finding that the trade collapse affected primarily durable goods (Eaton, Kortum, Neiman, and Romalis. 2013) and in particular investment goods and the automotive industry. Interestingly, almost two thirds of the decline in exports in Germany and Italy was driven by a contraction in trade volumes (while is more than half in France and Spain). Such evidence suggests that where trade in differentiated products was predominant the great collapse affected quantities more than prices (Gopinath, Itskhoki, Neiman, 2012).

In what follows we measure the role played by each of the three components in explaining market share growth over the period, by computing the contribution of each effect to the overall observed variance (along with the covariance). Table 3 reports variance and covariance terms for Euro Zone and three benchmark economies: United States, Japan and China. The table is organized as follows: the first column of estimates $(\operatorname{var}(G))$ indicates the variance of country export growth (in "volumes", i.e. changes in quantities); while each of the following columns reports a different component. There are four variance and six covariance terms: each of them is expressed as percentage of the total variance $(\operatorname{var}(\mathrm{G}))$. 
Table 3: Variance and covariance analysis of countries performance (2006q1-2014q3)

\begin{tabular}{|c|c|c|c|c|c|c|c|c|c|c|c|}
\hline & & \multicolumn{4}{|c|}{ VARIANCE } & \multicolumn{6}{|c|}{ COVARIANCE } \\
\hline & $\operatorname{var}(G)$ & $\begin{array}{c}\text { Gworld } \\
\text { (1) }\end{array}$ & $\begin{array}{c}\text { Gmktsh } \\
\text { (2) }\end{array}$ & $\begin{array}{c}\text { Gsec } \\
\text { (3) }\end{array}$ & $\begin{array}{c}\text { Ggeo } \\
\text { (4) }\end{array}$ & (1)-(2) & (1)-(3) & (1)-(4) & (2)-(3) & (2)-(4) & (3)-(4) \\
\hline AUT & 0.0066 & $47 \%$ & $11 \%$ & $5 \%$ & $8 \%$ & $-2 \%$ & $25 \%$ & $10 \%$ & $-4 \%$ & $-6 \%$ & $5 \%$ \\
\hline BEL & 0.0026 & $122 \%$ & $23 \%$ & $4 \%$ & $10 \%$ & $-55 \%$ & $-6 \%$ & $4 \%$ & $7 \%$ & $-8 \%$ & $-1 \%$ \\
\hline CYP & 0.0977 & $3 \%$ & $75 \%$ & $4 \%$ & $1 \%$ & $2 \%$ & $-3 \%$ & $-1 \%$ & $13 \%$ & $5 \%$ & $1 \%$ \\
\hline DEU & 0.0080 & $39 \%$ & $3 \%$ & $8 \%$ & $3 \%$ & $4 \%$ & $31 \%$ & $8 \%$ & $1 \%$ & $0 \%$ & $4 \%$ \\
\hline ESP & 0.0035 & $90 \%$ & $16 \%$ & $5 \%$ & $6 \%$ & $-29 \%$ & $22 \%$ & $-3 \%$ & $2 \%$ & $-4 \%$ & $-5 \%$ \\
\hline $\mathrm{EST}$ & 0.0185 & $17 \%$ & $105 \%$ & $1 \%$ & $13 \%$ & $-34 \%$ & $2 \%$ & $21 \%$ & $3 \%$ & $-30 \%$ & $3 \%$ \\
\hline FIN & 0.0102 & $31 \%$ & $22 \%$ & $3 \%$ & $5 \%$ & $6 \%$ & $4 \%$ & $15 \%$ & $5 \%$ & $9 \%$ & $2 \%$ \\
\hline FRA & 0.0035 & $91 \%$ & $14 \%$ & $3 \%$ & $4 \%$ & $-24 \%$ & $5 \%$ & $4 \%$ & $0 \%$ & $2 \%$ & $0 \%$ \\
\hline GRC & 0.0043 & $72 \%$ & $108 \%$ & $13 \%$ & $12 \%$ & $-60 \%$ & $-54 \%$ & $0 \%$ & $33 \%$ & $-21 \%$ & $-3 \%$ \\
\hline IRL & 0.0041 & $76 \%$ & $111 \%$ & $28 \%$ & $2 \%$ & $-81 \%$ & $-77 \%$ & $12 \%$ & $40 \%$ & $-5 \%$ & $-4 \%$ \\
\hline ITA & 0.0061 & $51 \%$ & $4 \%$ & $6 \%$ & $4 \%$ & $12 \%$ & $18 \%$ & $2 \%$ & $3 \%$ & $0 \%$ & $1 \%$ \\
\hline LUX & 0.0158 & $20 \%$ & $104 \%$ & $3 \%$ & $2 \%$ & $-38 \%$ & $11 \%$ & $2 \%$ & $-9 \%$ & $4 \%$ & $1 \%$ \\
\hline MLT & 0.0368 & $9 \%$ & $63 \%$ & $11 \%$ & $1 \%$ & $-4 \%$ & $5 \%$ & $1 \%$ & $13 \%$ & $1 \%$ & $1 \%$ \\
\hline NLD & 0.0026 & $118 \%$ & $44 \%$ & $6 \%$ & $11 \%$ & $-26 \%$ & $-46 \%$ & $12 \%$ & $1 \%$ & $-17 \%$ & $-3 \%$ \\
\hline PRT & 0.0025 & $128 \%$ & $58 \%$ & $6 \%$ & $17 \%$ & $-86 \%$ & $19 \%$ & $-3 \%$ & $1 \%$ & $-35 \%$ & $-4 \%$ \\
\hline SVK & 0.0082 & $38 \%$ & $39 \%$ & $11 \%$ & $10 \%$ & $-33 \%$ & $37 \%$ & $16 \%$ & $-21 \%$ & $-7 \%$ & $10 \%$ \\
\hline SVN & 0.0070 & $44 \%$ & $7 \%$ & $7 \%$ & $16 \%$ & $-13 \%$ & $29 \%$ & $16 \%$ & $-7 \%$ & $-4 \%$ & $4 \%$ \\
\hline $\mathrm{CHN}$ & 0.0090 & $35 \%$ & $26 \%$ & $2 \%$ & $1 \%$ & $35 \%$ & $6 \%$ & $0 \%$ & $0 \%$ & $-5 \%$ & $0 \%$ \\
\hline JPN & 0.0168 & $19 \%$ & $14 \%$ & $11 \%$ & $3 \%$ & $21 \%$ & $27 \%$ & $-4 \%$ & $16 \%$ & $-3 \%$ & $-3 \%$ \\
\hline USA & 0.0056 & $56 \%$ & $19 \%$ & $1 \%$ & $2 \%$ & $22 \%$ & $11 \%$ & $-6 \%$ & $2 \%$ & $-7 \%$ & $-1 \%$ \\
\hline WLD & 0.0031 & $100 \%$ & $0 \%$ & $0 \%$ & $0 \%$ & $0 \%$ & $0 \%$ & $0 \%$ & $0 \%$ & $0 \%$ & $0 \%$ \\
\hline
\end{tabular}

Source: Measuring Export Competitiveness database (World Bank, International Trade Centre \& Bank of France).

The first column is the variance of the volume of merchandise exports of each country, which is afterwards decomposed in 10 contributions. For instance, Austria (first cell) has a variance of its exports in volume, over the 2006q1-2014q3 period, which is explained firstly by the variance of world export growth (47\%), then by the covariance between world export growth and the product composition of Austrian exports (25\%), then by the variance of the competitiveness effect for Austria (11\%), and so on for the remaining contributions.

Based on this decomposition and starting with the grey shaded panel, we observe, not surprisingly, that the quarterly volatility of export growth is inversely related to country export variability: the lower the variance, the higher the contribution of aggregate volatility. Column 2 shows the volatility of the pure competitiveness effect, while Columns 3 and 4 report the volatility of the composition factors (sectoral and geographical). The right hand side panel reports the co-variances. Moving to the covariance panel, the first column shows the covariance between the world trade growth (aggregate volatility, common to all countries) and the competitiveness factor (country specific). Similarly the second and third columns report the covariance between world trade and sectoral (1-3) and geographical (1-4) effects.

The following two columns report the covariance between the competitiveness factor and the sectoral component (2-3) and the geographical factors (2-4). Finally, the last column reports the covariance between geographic and sectoral composition effects. In general, negative co-variance with world export 
indicates anti-cyclical behaviour, while low variability of export growth is possibly associated with a greater diversification of the export basket. Countries like Belgium, Netherlands, Portugal and France show the lowest export growth variability among the selected economies. Moreover, Belgium and Netherlands also show a negative covariance term between world export volatility. Competitiveness or sector composition effects are counter-cyclical: countries they tend to lose market shares when world trade is expanding and consolidate when export growth is sluggish (see column 1-2 and 1-3 respectively).

Both Germany and Italy reports a slightly higher volatility of exports mainly driven (especially for Italy) by a positive covariance between world trade and country competitiveness effect along with a positive covariance with the sector composition of exports. For those countries the overall market share development seems to be significantly affected by aggregate demand conditions.

As pointed out by Gaulier at al. (2015) the drop in the supply of exports by China since 2011 along with the contraction in demand from the euro area seems to be the two most important contributors to crosscountry reallocations of trade flows during the 2010s. Their conclusion suggests that the recent trade slowdown is a combination of two main factors: a natural phasing out of the effect of lower trade costs and the significant negative demand shock in the euro area. Where the latter was followed by a reorientation of production towards domestic demand in China (this evidence is consistent with recent works by Kee and Tang, 2012; Lemoine et al. 2014; Koopman et al, 2012). However, as suggested in Gaulier et al., another relevant ingredient shaping world trade patterns is the evolution of GVCs: after a remarkable development during the 1990s and 200s its expansions has slowed down during the 2010s, and by consequence the associated trade.

Table 4: Contributions of sectorial specialization, BEC categories, quantities vs. values (All countries)

\begin{tabular}{|l|cccc|}
\hline \multicolumn{1}{|c}{} & \multicolumn{4}{c|}{ Quantities } \\
\hline pre crisis & CONS & INT & CAP & PRIM \\
crisis \& rebound (08q4-11q2) & $-0.3 \%$ & $0.5 \%$ & $0.5 \%$ & $-1.9 \%$ \\
post crisis (11q3-14q3) & $-0.4 \%$ & $0.3 \%$ & $-0.8 \%$ & $-0.4 \%$ \\
ALL & $0.3 \%$ & $-0.3 \%$ & $-0.3 \%$ & $-0.8 \%$ \\
\hline \multicolumn{1}{|c}{$-0.1 \%$} & $0.1 \%$ & $-0.2 \%$ & $-1.0 \%$ \\
\hline pre crisis & CONS & INT & CAP & PRIM \\
crisis \& rebound (08q4-11q2) & $-3.9 \%$ & $0.8 \%$ & $-5.3 \%$ & $9.4 \%$ \\
post crisis (11q3-14q3) & $0.5 \%$ & $0.4 \%$ & $-1.0 \%$ & $-2.2 \%$ \\
ALL & $1.0 \%$ & $-0.4 \%$ & $-1.2 \%$ & $-0.3 \%$ \\
\hline
\end{tabular}

Note=contribution of consumption (CONS), intermediate (INT), capital (CAP), and primary (PRIM) goods to export growth. Source: Gaulier et al. (2015).

Taking trade in intermediate goods as proxy for GVC, Table 4 shows that it was contributing on average with $0.5 \%$ growth per annum before the crisis and it is contributing since $2011 \mathrm{q} 3$ with a negative $0.3 \%$ annually, in quantities. The retrenching of GVC trade is evident from the different dynamics of trade in consumption goods that followed the opposite pattern (negative $0.3 \%$ before the crisis and positive $0.3 \%$ after the crisis).

Along with demand and supply factors the increasing interdependence of countries in the context of GVCs appears to be a key element to understand and project the future geography of trade and production. 


\section{EUROPE GVCS’ PARTICIPATION}

International intra-firm flows of goods, capital and knowledge are key components of the increasingly dense global production network. Multinational firms are able to optimize production stages across countries according to local comparative advantages. A key feature of the emergence of such complex international production linkages during the last decades (during the "second unbundling”, Baldwin 2006), is that they have contributed significantly to the acceleration of global trade, i.e. increasing the foreign inputs contains of a country exports as well as domestic consumption.

At the same time, evidence from Johnson and Noguera (2012) shows that distance matters in shaping bilateral Value Added flows, driving the emergence of a clear regional structure: factory Asia, factory North America and factory Europe (Baldwin and Lopez, 2013); suggesting that the same process has also reinforced regional ties. In such a context knowing the origin of the value added content of exports, foreign or domestic, is a crucial element to assess not only how much of the exports from a given country are made using foreign inputs but also its role in a fragmented production chain.

Buying and selling patterns of value added, in fact, can reveal useful insights on a country relative position within the GVC network. From selling country perspective, final destination of domestic value added is crucial to evaluate the degree of exposure to foreign demand shocks. From sourcing country perspective, instead, origin of foreign value added used in domestic production (for exports as well as for final consumption) helps to identify the potential source of technology and productivity spillovers (through intra-firm and arm's length transfer).

Table 5: Decomposition of Value Added in trade in the Euro Area (as a whole)

\begin{tabular}{l|rrrr|rrrr|rrrr}
\hline & \multicolumn{3}{|c|}{$\begin{array}{c}\text { Foreign value added in } \\
\text { exports in \% of extra area } \\
\end{array}$} & \multicolumn{4}{|c|}{ exports } & \multicolumn{3}{c|}{$\begin{array}{c}\text { Domestic value added in } \\
\text { imports in \% of extra area } \\
\text { imports }\end{array}$} & \multicolumn{3}{|c|}{$\begin{array}{c}\text { Re-exported domestic value } \\
\text { added in imports in \% of } \\
\text { extra area exports }\end{array}$} \\
\hline Euro Area & 2000 & 2007 & 2009 & 2011 & 2000 & 2007 & 2009 & 2011 & 2000 & 2007 & 2009 & 2011 \\
USA & 16.4 & 19.1 & 17.7 & 21.2 & 6.0 & 7.1 & 6.1 & 5.7 & 1.0 & 1.4 & 1.1 & 1.2 \\
China & 10.6 & 13.3 & 11.4 & 14.9 & 8.2 & 5.6 & 4.9 & 4.6 & 0.9 & 0.7 & 0.6 & 0.7 \\
Japan & 17.3 & 24.7 & 19.3 & 21.8 & 1.2 & 3 & 3.1 & 3.2 & 0.2 & 0.7 & 0.6 & 0.7 \\
\hline & 8.5 & 15.4 & 13.4 & 17 & 2.6 & 2.1 & 1.7 & 1.5 & 0.2 & 0.3 & 0.2 & 0.3 \\
\hline
\end{tabular}

Source: Amador et al. (2015)

Recently Amador et al. (2015) analyzed value added patterns in the Euro Area (EA) showing that in 2011 the share of foreign value added for the EA as a whole was higher than for Japan or United States - see Table 5. Noteworthy, most of the foreign value added content in EA is sourced within member countries, suggesting that (we quote Amador et al.): "the growing relevance of suppliers external to the euro area does not reflect a weakening of the production links within the monetary union, being instead a substitution of each country's domestic value added by extra euro area sourcing”.

From a country perspective, however, domestic value added contents of gross exports and its evolution over time is interesting as well. The value added generated domestically (directly and indirectly) from export activity, in fact, as a function of productivity, is a critical indicator on country specialization ${ }^{8}$.

8 See Appendix A for a decomposition of the value added content of gross export. 
Figure 2 reports the compound annual growth rate (CAGR) of domestic value added content of gross exports over the period 1995-2009 ${ }^{9}$. On average, European countries domestic content value added increases of about $5.8 \%$ during the period.

Figure 2: Growth of Domestic Value Added embodied in Gross Exports, 1995-2009

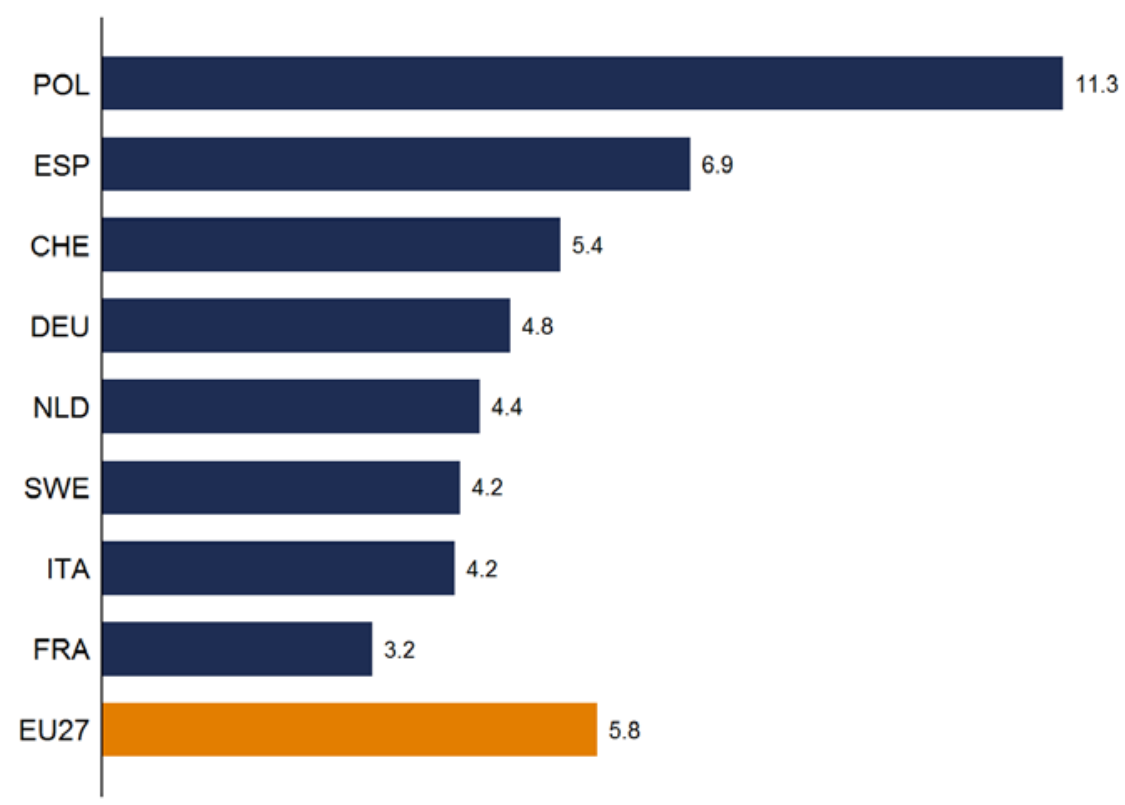

Source: Own calculation on data OECD TiVA.

Figure 3: Domestic Value Added Embodied in Gross Exports (\% Gross Exports)

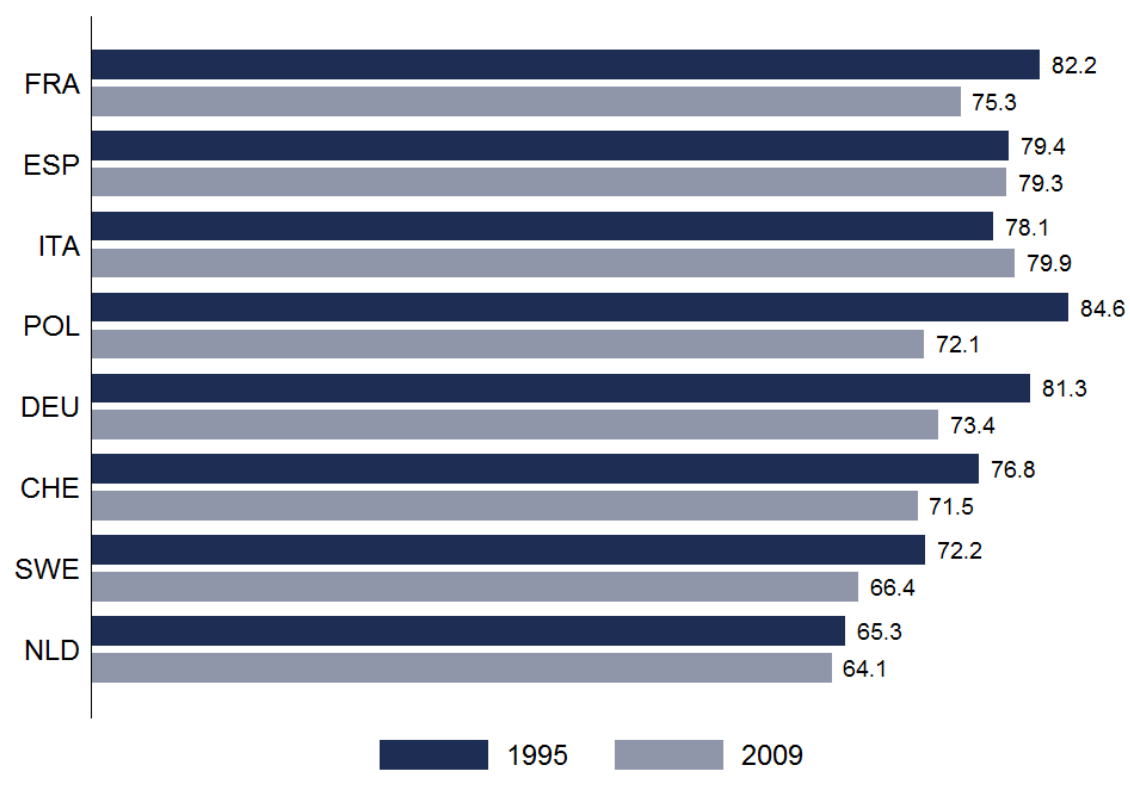

Source: Own calculation on data OECD TiVA.

9 Compound annual growth rate (CAGR) between time $\mathrm{t}$ and $\mathrm{t}-\mathrm{k}$ is defined as: $\operatorname{CAGR}_{t}=\left(X_{t} / X_{t-k}\right)^{\frac{1}{k}}-1$ where $\mathrm{k}$ is the number of years. 
Figure 4: Country Value Added Embodied in Third Country Exports (\% Gross Exports)

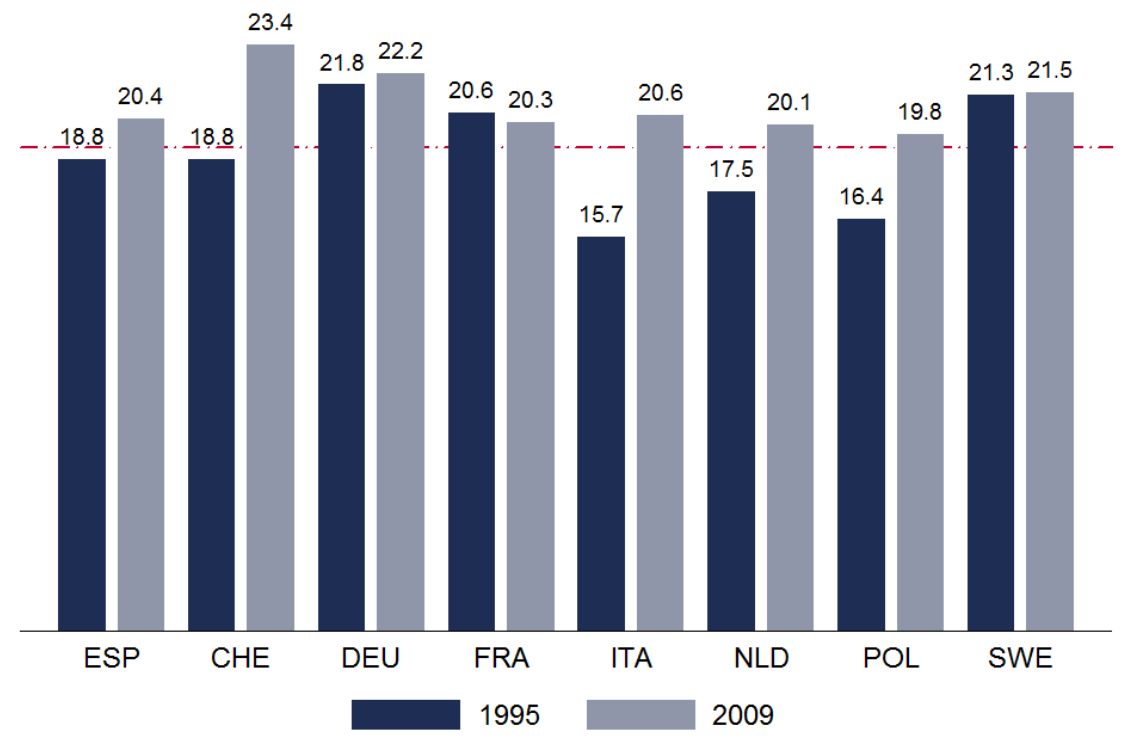

Source: Own calculation on data OECD TiVA.

Noteworthy, absolute increase in domestic value added is much more pronounced in Eastern European countries (Poland $+11.3 \%$ ) than in mature economies like France (3.2\%) or Italy $(4.2 \%)$. Nevertheless, if expressed in relative terms (as percentage of gross exports) domestic value added content decreased significantly from 1995 to 2009, see Figure 3. Poland registered the highest contraction: -12.5\%, followed by Germany $-7.9 \%$ and France $-6.9 \%$, on the contrary Italy registered a slight increase in the share of domestic value added on gross exports $+1.8 \%$. In general, bigger economies tend to report a higher share of domestic value added (France, Italy and Spain) likely because they can count on more efficient national value chains. Interestingly, such evidence does not apply to Germany, which is less dependent on domestic value added with respect to other comparable economies (as shown also in UNCTAD $2014^{10}$ ). Indeed, most countries have intensified their dependency on foreign value added relative to exports, signaling an increase reliance on cross-country production networks. Notable exceptions are Spain unchanged between 1995 and 2009 - and especially Italy which decreases its share of foreign value added (-1.8\%, see Figure A.3).

Turning to a selling country perspective, Figure 4, European countries increase the share of domestic value added embodied in third country exports (as percentage of their own gross exports). Over the whole period the average value is about $19.3 \%$ (red dashed line Figure 4). At the country level, it is worth noticing the sharp rise of Switzerland and Italy as value added suppliers for other countries exports, $+4.6 \%$ and $+4.9 \%$ respectively. In the case of Italy, this evidence is not at odds with previous remarks of a decrease in foreign value added contribution on country's gross exports; on the contrary it confirms the needs to separate the selling versus buying perspective in judging overall country participation in GVC.

Figure 4 and 5 reports the main origin and destination countries of value added for Germany and France in year 2009. Both figures are constructed such as Buying side (blue bars) sum up to the share of foreign value added embodied in country gross exports, while Selling side (orange bars) sum up to the domestic value added embodied in third country exports (as percentages of selling country gross exports). In the

10 The evidence reported in UNCTAD 2014 is obtained using a different data source: the UNCTAD-Eora GVC Database. 
case of Germany Figure 4 shows that $2.7 \%$ of national gross exports are depending on value added sourced from United States, followed by France (1.9\%), United Kingdom (1.8\%) and Italy (1.7\%) ${ }^{11}$. On the selling side United States represents a relatively marginal destination for German value added, while intra-European linkages seems to be far more binding, especially with neighboring partners: France (1.9\%), Netherlands (1.4\%), Switzerland (1.4\%) and Italy (1.3\%). Interestingly, China is becoming a major destination market for Germany, about $1.7 \%$ of overall national gross exports consist of domestic value added transferred to China.

Moving to France, Figure 5, intra-EU interdependence is far stronger, 3.8\% of the overall French gross exports depend upon German value added ${ }^{12}$, followed by United States (3\%) and Italy (1.8\%). On the Selling side more than 5\% of France exports take the form of value added transferred to Germany (3.7\%) and Belgium (1.6\%), followed by China (1.4\%). Comparing value added trade structure of the two countries it emerges clearly that German value added network is far more diversified than the French one: on either the selling or buying side, France shows a 50\% higher concentration of value added flows with respect to Germany ${ }^{13}$. Meaning that more concentrated countries may be more exposed to foreign country demand shocks (selling perspective) as well as less open to foreign technology transfer (buying perspective).

Considering value added trade in the transport sector the market appears to be highly concentrated across three main suppliers: United States (19\%), Germany (18.1\%) and Japan (12.4\%). In terms of individual flows more than half of US exports are concentrated in only three destination markets: France $(4.7 \%$ of world VA trade) Canada (3.9\%) and Germany (2.2\%). German out-flows of value added are relatively more differentiated, even if most of them are concentrated within Europe; 32\% (of country VA export) goes too France, Austria and Spain, and 23\% to Czech Republic, Slovakia, Poland and Hungary. From the buyer side, Germany is by far the most relevant market for value added in transports sector, absorbing almost $18 \%$ of world flows, followed by France $10 \%$ and Canada $6.6 \%$.

11 Out of $26.6 \%$ of overall foreign value added in national gross exports those figures translates into a sourcing country market share of 10\% (USA), 7.1\% (FRA), 6.7\% (GBR) and 6:3\% (ITA).

12 Account for $15 \%$ of the overall foreign value added content of French gross exports.

13 The degree of concentration is derived as the relative difference in the Herfindahl-Hirschman index on value added shares distribution. 
Figure 5: Sourcing and Selling pattern, Germany, year 2009 (total economy, \% gross exports)

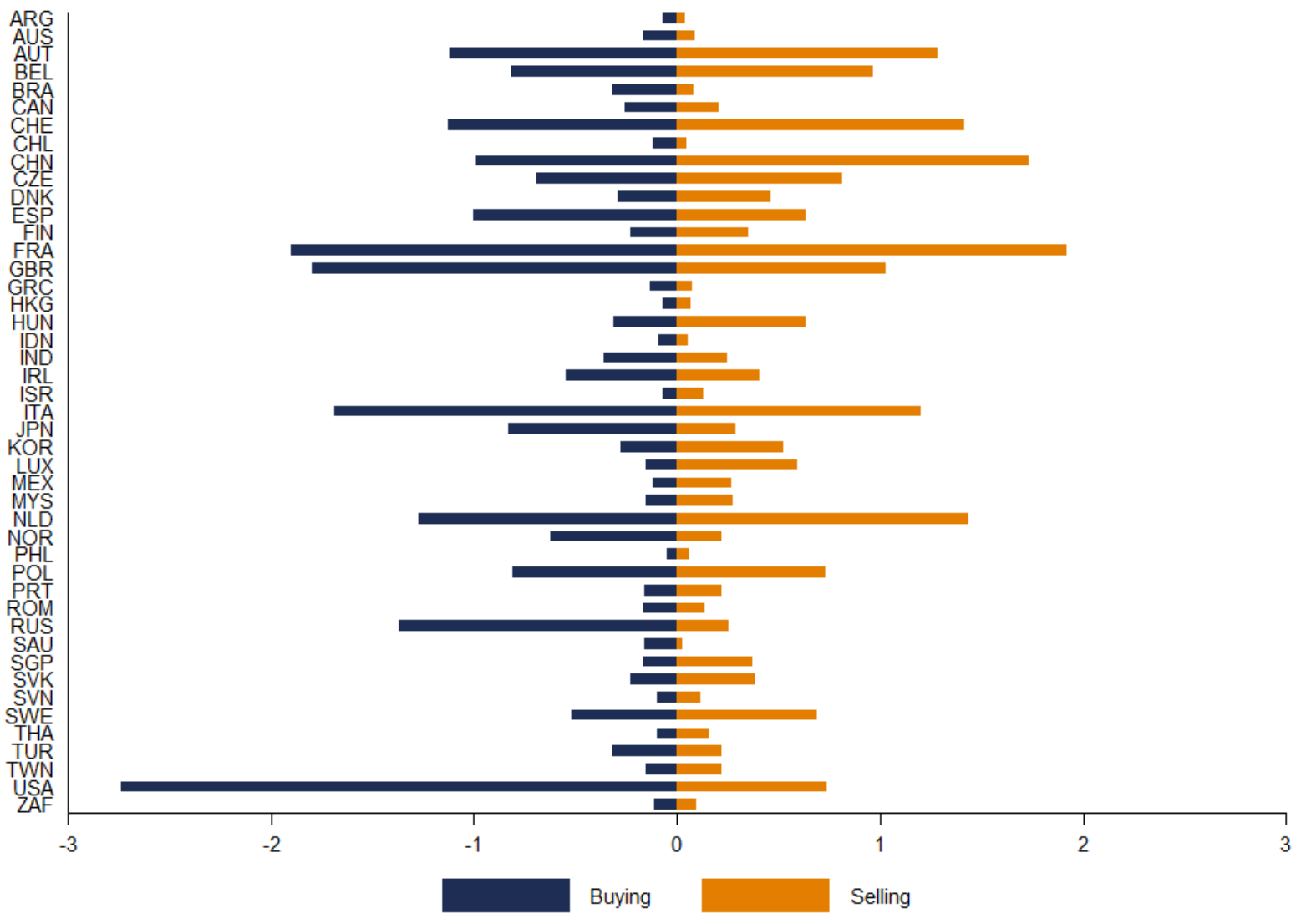

Source: Own calculation on data OECD TiVA. Buying side values needs to be read as positive shares. 
Figure 6: Sourcing and Selling pattern, France, year 2009 (total economy, \% gross exports)

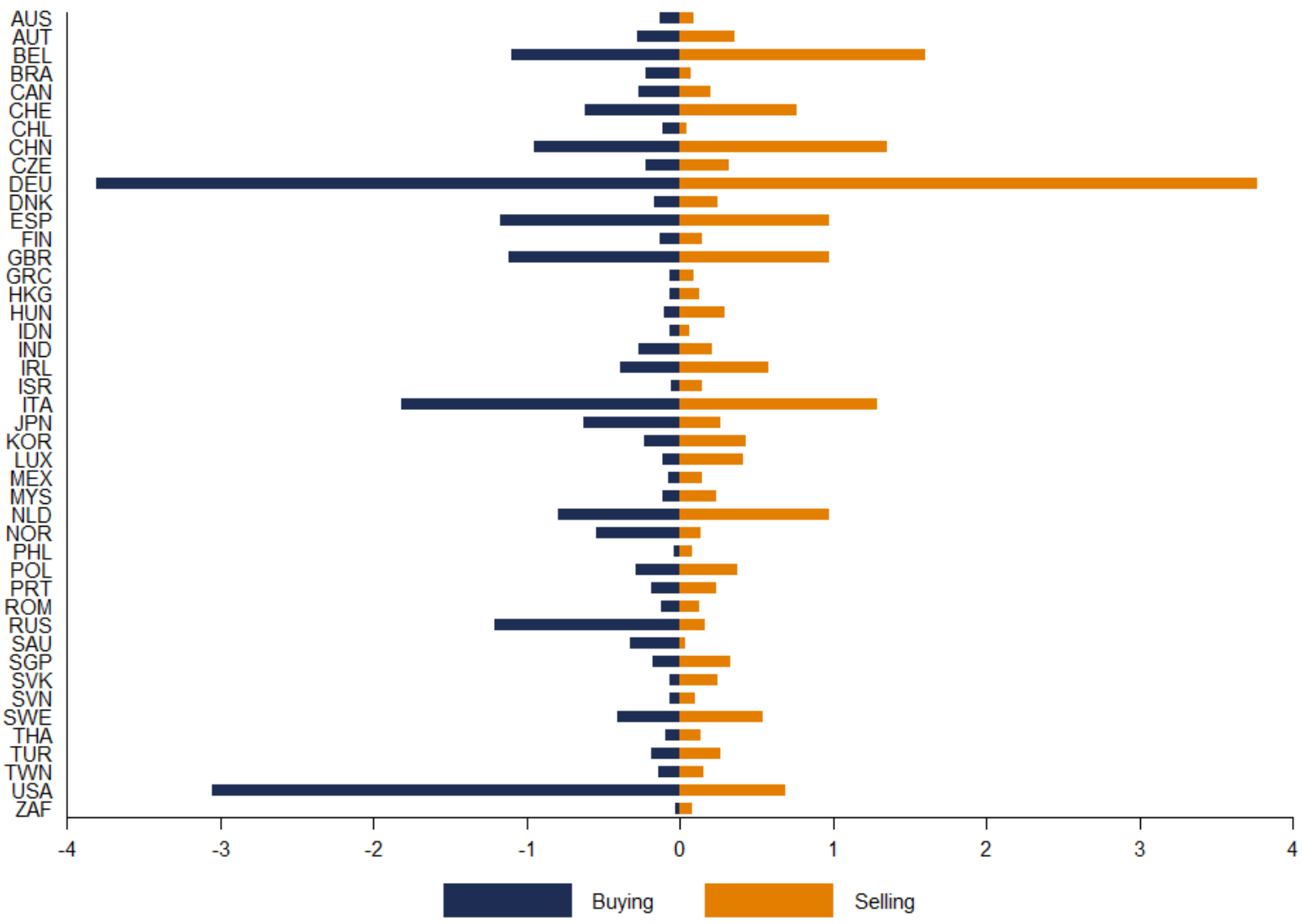

Source: Own calculation on data OECD TiVA. Buying side values needs to be read as positive shares.

Santoni and Taglioni (2015) measure the correlation between the growth rate of gross exports and the direct (intra-sector) domestic value added in gross exports, EXGRDDC, the indirect (upstream) domestic value added, EXGRIDC, and the foreign value added embodied in gross exports, EXGRFVA. Correlations are computed using a fixed effect regression on first differenced variables. Estimating a Random Trend Model, they are able to control for individual specific trends along with time invariant unobserved heterogeneity. Taking first differences of the baseline equation, in fact, remove the individual specific fixed effect and reduce any individual specific time trend in the considered variables to a constant. Estimating the differenced data using Fixed Effects allows to condition out individual specific trend14.

The estimated equation reads as follow:

14 Intuitively, this procedure helps to remove most of the unobserved heterogeneity in the data, see Wooldrige (2010) for further details. 


$$
\Delta \ln \left(\operatorname{Exp}_{c s t}\right)=\alpha+\beta_{1} \Delta \ln \left(\operatorname{Dir}_{c s t}\right)+\beta_{2} \Delta \ln \left(\operatorname{Ind}_{c s t}\right)+\beta_{3} \Delta \ln \left(\text { For }_{c s t}\right)+\delta_{c s}+\delta_{t}+\varepsilon_{c s t}
$$

Where $\Delta$ designates $\log$ differences: $\left[\ln \left(E x p_{c s t}\right)-\ln \left(\operatorname{Exp}_{c s t-1}\right)\right]$. All correlations control for countrysector and year fixed effects, $\delta_{c s}$ and $\delta_{t}{ }^{15}$. The data are based on the OECD-WTO TiVA Dataset and available for 56 OECD and non-OECD countries and 18 sectors (2 primary sectors, 9 manufacturing sectors, and 7 services sectors), and cover the years 1995, 2000, 2005, 2008 and 2009.

Results are reported in Table 5 and confirm that all value added components are positively correlated with gross exports, suggesting that export growth benefits all participants' by expanding their value added. When considering all sectors pooled, the domestic value added embodied in gross exports (EXGRDDC, Table 5) shows the highest correlation with gross export growth (0.500). Meanwhile, for the overall manufacturing sectors, domestic and foreign value added shows the same order of magnitude, 0.400 and 0.362. Interestingly, for services industries the correlation between exports and domestic direct value added is the highest (0.544) while the association of gross exports and foreign value added seems to be weaker.

Table 6: Decomposition of gross export growth, Full Sample, various years

\begin{tabular}{|c|c|c|c|c|c|}
\hline Dep Var: Gross Export (EXGR) & All & Manuf & Services & Traditional & Business \\
\hline EXGRDDC (Dir) & $\begin{array}{l}0.500 * * * \\
(0.029)\end{array}$ & $\begin{array}{l}0.400 * * * \\
(0.032)\end{array}$ & $\begin{array}{l}0.544 * * * \\
(0.042)\end{array}$ & $\begin{array}{l}0.639 * * * \\
(0.018)\end{array}$ & $\begin{array}{l}0.567 * * * \\
(0.021)\end{array}$ \\
\hline EXGRIDC (Ind) & $\begin{array}{l}0.227 * * * \\
(0.018)\end{array}$ & $\begin{array}{l}0.227 * * * \\
(0.022)\end{array}$ & $\begin{array}{l}0.261^{* * *} \\
(0.024)\end{array}$ & $\begin{array}{l}0.215^{* * *} \\
(0.025)\end{array}$ & $\begin{array}{l}0.240 * * * \\
(0.019)\end{array}$ \\
\hline EXGRFVA (For) & $\begin{array}{l}0.266 * * * \\
(0.020)\end{array}$ & $\begin{array}{l}0.362 * * * \\
(0.025)\end{array}$ & $\begin{array}{l}0.189 * * * \\
(0.023)\end{array}$ & $\begin{array}{l}0.149 * * * \\
(0.020)\end{array}$ & $\begin{array}{l}0.187^{* * *} \\
(0.016)\end{array}$ \\
\hline Constant & $\begin{array}{l}-0.007 * * \\
(0.003)\end{array}$ & $\begin{array}{l}-0.007 * \\
(0.004)\end{array}$ & $\begin{array}{l}-0.009 \\
(0.006)\end{array}$ & $\begin{array}{l}-0.006 \\
(0.004)\end{array}$ & $\begin{array}{l}0.003 \\
(0.004)\end{array}$ \\
\hline Observations & 3,975 & 2,041 & 1,489 & 674 & 456 \\
\hline R-squared & 0.989 & 0.989 & 0.994 & 0.997 & 0.997 \\
\hline
\end{tabular}

Note 1: In parentheses standard errors clustered at the country-by-sector level. ${ }^{* * *} \mathrm{p}<0.01,{ }^{* *} \mathrm{p}<0.05,{ }^{*} \mathrm{p}<0.1$. All variables are in logs, Year and Country-by-Sector dummies, not reported, are included in all regressions.

Note 2: EXGRDDC: direct (intra-sector) domestic value added in gross exports

EXGRIDC: indirect (upstream) domestic value added

EXGRFVA: foreign value added embodied in gross exports

Source: Santoni and Taglioni (2015).

\footnotetext{
${ }^{15}$ Re-imported domestic value added is not included in the regression since in many cases the value is 0 resulting in a significant reduction of the estimation sample after taking natural logarithms.
} 
Table 7: Decomposition of gross export growth by sectors, various years (Full Sample)

\begin{tabular}{|c|c|c|c|c|c|c|c|c|}
\hline $\begin{array}{l}\text { Dep Var: } \\
\text { Gross Export }\end{array}$ & All & Manuf & Food & Text & Chem & Mac & Elect & Transp \\
\hline EXGRDDC & $\begin{array}{c}0.510 * * * \\
(0.034)\end{array}$ & $\begin{array}{c}0.441^{* * *} \\
(0.031)\end{array}$ & $\begin{array}{c}0.297 * * * \\
(0.025)\end{array}$ & $\begin{array}{c}0.455^{* * *} \\
(0.051)\end{array}$ & $\begin{array}{c}0.404^{* * *} \\
(0.051)\end{array}$ & $\begin{array}{c}0.459 * * * \\
(0.033)\end{array}$ & $\begin{array}{c}0.553^{* * *} \\
(0.080)\end{array}$ & $\begin{array}{c}0.495^{* * *} \\
(0.078)\end{array}$ \\
\hline$E X G R D D C * E A$ & $\begin{array}{l}-0.087 \\
(0.059)\end{array}$ & $\begin{array}{c}-0.136 * * \\
(0.058)\end{array}$ & $\begin{array}{c}-0.135^{* * *} \\
(0.040)\end{array}$ & $\begin{array}{c}0.055 \\
(0.074)\end{array}$ & $\begin{array}{c}0.062 \\
(0.062)\end{array}$ & $\begin{array}{l}-0.058 \\
(0.047)\end{array}$ & $\begin{array}{c}-0.152 * \\
(0.087)\end{array}$ & $\begin{array}{l}-0.083 \\
(0.080)\end{array}$ \\
\hline EXGRIDC & $\begin{array}{c}0.238 * * * \\
(0.024)\end{array}$ & $\begin{array}{c}0.234 * * * \\
(0.030)\end{array}$ & $\begin{array}{c}0.490 * * * \\
(0.031)\end{array}$ & $\begin{array}{c}0.229 * * * \\
(0.042)\end{array}$ & $\begin{array}{c}0.249 * * * \\
(0.054)\end{array}$ & $\begin{array}{c}0.219 * * * \\
(0.028)\end{array}$ & $\begin{array}{c}0.065 \\
(0.094)\end{array}$ & $\begin{array}{c}0.211^{* * *} \\
(0.040)\end{array}$ \\
\hline$E X G R I D C^{*} E A$ & $\begin{array}{l}-0.031 \\
(0.034)\end{array}$ & $\begin{array}{l}-0.042 \\
(0.037)\end{array}$ & $\begin{array}{l}-0.145 \\
(0.130)\end{array}$ & $\begin{array}{l}-0.006 \\
(0.055)\end{array}$ & $\begin{array}{c}-0.118^{*} \\
(0.059)\end{array}$ & $\begin{array}{l}-0.013 \\
(0.042)\end{array}$ & $\begin{array}{c}0.086 \\
(0.105)\end{array}$ & $\begin{array}{c}-0.119 * * \\
(0.050)\end{array}$ \\
\hline EXGRFVA & $\begin{array}{c}0.249 * * * \\
(0.026)\end{array}$ & $\begin{array}{c}0.324 * * * \\
(0.029)\end{array}$ & $\begin{array}{c}0.226 * * * \\
(0.025)\end{array}$ & $\begin{array}{c}0.291^{* * * *} \\
(0.040)\end{array}$ & $\begin{array}{c}0.337 * * * \\
(0.040)\end{array}$ & $\begin{array}{c}0.321^{* * * *} \\
(0.030)\end{array}$ & $\begin{array}{c}0.383^{* * * *} \\
(0.091)\end{array}$ & $\begin{array}{c}0.318^{* * * *} \\
(0.034)\end{array}$ \\
\hline$E X G R F V A * E A$ & $\begin{array}{c}0.096^{* *} \\
(0.038)\end{array}$ & $\begin{array}{c}0.148^{* * *} \\
(0.041)\end{array}$ & $\begin{array}{c}0.240 * * \\
(0.097)\end{array}$ & $\begin{array}{l}-0.007 \\
(0.056)\end{array}$ & $\begin{array}{c}0.072 \\
(0.049)\end{array}$ & $\begin{array}{c}0.067 \\
(0.052)\end{array}$ & $\begin{array}{c}0.080 \\
(0.097)\end{array}$ & $\begin{array}{c}0.177^{* * *} \\
(0.060)\end{array}$ \\
\hline Constant & $\begin{array}{c}-0.010 * * * \\
(0.003)\end{array}$ & $\begin{array}{c}-0.010 * * * \\
(0.003)\end{array}$ & $\begin{array}{l}-0.007 \\
(0.010)\end{array}$ & $\begin{array}{c}0.003 \\
(0.007)\end{array}$ & $\begin{array}{l}-0.000 \\
(0.007)\end{array}$ & $\begin{array}{c}-0.011^{* *} \\
(0.005)\end{array}$ & $\begin{array}{l}-0.007 \\
(0.012)\end{array}$ & $\begin{array}{c}-0.022^{* *} \\
(0.008)\end{array}$ \\
\hline $\begin{array}{l}\text { Observations } \\
\text { R-squared }\end{array}$ & 3.587 & 2.041 & 224 & 224 & 224 & 217 & 224 & 223 \\
\hline $\begin{array}{l}\text { Note 1: In parenth } \\
\text { Year and Country } \\
\text { classifications ava } \\
\text { dummy variable ed } \\
\text { since the classifica } \\
\text { fixed effects. } \\
\text { Note 2: EXGRD } \\
\text { EXGRID } \\
\text { EXGRF } \\
\text { Source: Santoni an }\end{array}$ & $\begin{array}{l}\text { es standard e } \\
\text { lummies, not } \\
\text { ble in TiVA: } \\
\text { al to } 1 \text { for th } \\
\text { on do not char } \\
\text { C: direct (intr } \\
\text { : indirect (up } \\
\text { A: foreign val } \\
\text { Taglioni (201 }\end{array}$ & $\begin{array}{l}\text { repors clustere } \\
\text { reported, are } \\
\text { Food (15-16 } \\
\text { Euro Area c } \\
\text { ge over the e } \\
\text {-sector) dom } \\
\text { tream) dome } \\
\text { le added emb } \\
\text { 5) }\end{array}$ & $\begin{array}{l}\text { at the count } \\
\text { included in a } \\
\text {, Text (17-19 } \\
\text { ountries: Aut, } \\
\text { timation sam } \\
\text { stic value adc } \\
\text { tic value adde } \\
\text { died in gross }\end{array}$ & $\begin{array}{l}\text { Chem (23 } \\
\text { Bel, Deu, } \\
\text { le (1995-20 } \\
\text { ed in gross } \\
\text { exports }\end{array}$ & $\begin{array}{l}.01,{ }^{* *} \mathrm{p} \\
\text { ndustries a } \\
\text { Mac (29) } \\
\text { Fin, Fra, G } \\
\text { the EA dun } \\
\text { rts }\end{array}$ & $\begin{array}{l}5, * \mathrm{p}<0 \\
\text { defined a } \\
\text { lect ( } 30-3 \\
\text { Irl, Ita, } \mathrm{L} \\
\text { y is captu }\end{array}$ & $\begin{array}{l}\text { ransp } \\
\text { rlt, Nl } \\
\text { y the c }\end{array}$ & $\begin{array}{l}\text { re in logs, } \\
\text { SIC rev } 3 \\
\text { ). EA is a } \\
\text { Svk, Snv; } \\
\text {-by-sector }\end{array}$ \\
\hline
\end{tabular}

Following the same empirical approach as Taglioni and Santoni (2015) we look at the correlations for Euro Area with respect to the overall sample within several manufacturing industries. Table 7 reports the estimated coefficients for Equation (1) including an interaction term between the value added components and a dummy for Euro Area's countries. Results show that on aggregate the conditional correlation between gross exports and foreign value added is higher for the EA countries (consistently with Amador et al. 2015). Estimation for the manufacturing sector alone confirms previous evidence along with a weaker correlation of exports with the domestic value added. Interestingly, sectoral analysis suggests that for Transport sector (Transp) the stronger correlation between exports and foreign value added is associated with a weaker role for indirect domestic value added.

From a policy perspective it is worth noting that a higher growth rate of foreign value added is always positively correlated with gross exports. In other words, imported inputs enable countries to increase their production and exports. 


\section{ECONOMIC PATTERNS AT THE 2035 HORIZON}

The key insights on the future geography of economic activity in Europe have been well documented in other research pillars of the "Value Added in Motion (VAM)" project: International Migration patterns (Docquier and Machado 2015); World Trade patterns (Fontagné and Fouré 2015); Macroeconomic implication of energy prices (Fontagné, Fouré and Santoni 2015). We now take stock of these findings.

\section{Migration patterns}

International migration is a crucial element in order to evaluate the location of economic activity in the near future; taking a longer horizon than 2035 Docquier and Machado (2015) provide worldwide projections of population, educational attainment and international migration. In their paper they develop a dynamic model for world economy which includes endogenous inequality, migration, fertility and education, linking emigration to human capital and population growth ${ }^{16}$. The outcome is a joint prediction of income inequality, population growth and migration flows for 195 countries over the $21^{\text {st }}$ century.

The main result from Docquier and Machado indicates that total factor productivity (TFP) growth in transition economies and Africa will have a significant impact on population and inequality. In particular, if technological convergence is associated with a decrease in migration costs world income would increase reducing inequality and migration pressure towards nowadays main destination countries.

Table 8: Predicted immigration rates in the baseline scenario (\% of labor force, 2000-2100)

\begin{tabular}{lccccc}
\hline & 2000 & 2025 & 2050 & 2075 & 2100 \\
\hline World & 3.5 & 4.0 & 4.4 & 4.5 & 4.4 \\
\hline USA & 13.2 & 15.2 & 15.8 & 14.3 & 12.5 \\
Australia & 28.1 & 26.1 & 26.1 & 25.9 & 24.8 \\
Canada & 22.5 & 22.3 & 23.1 & 22.2 & 20.2 \\
Japan & 1.0 & 1.0 & 1.2 & 1.3 & 1.3 \\
Switzerland & 23.8 & 24.4 & 25.4 & 25.7 & 25.7 \\
Saudi Arabia & 33.9 & 21.2 & 16.4 & 13.4 & 10.9 \\
South Africa & 3.8 & 3.8 & 4.6 & 5.7 & 6.7 \\
\hline EU15 & 7.5 & 10.9 & 14.1 & 16.1 & 17.2 \\
\hline France & 9.3 & 14.3 & 18.6 & 20.2 & 20.4 \\
Germany & 7.8 & 11.4 & 14.5 & 14.8 & 14.6 \\
Italy & 2.2 & 3.5 & 11.0 & 12.2 & 12.6 \\
Sweden & 12.2 & 16.6 & 20.8 & 23.0 & 23.6 \\
United Kingdom & 8.8 & 13.2 & 18.7 & 24.6 & 28.1 \\
\hline BRIC & 1.0 & 2.0 & 2.6 & 2.6 & 2.2 \\
\hline Brazil & 0.3 & 0.3 & 0.3 & 0.4 & 0.3 \\
Russia & 9.4 & 13.8 & 13.8 & 11.7 & 9.6 \\
India & 1.1 & 2.8 & 4.0 & 3.9 & 3.2 \\
China & 0.0 & 0.0 & 0.0 & 0.1 & 0.1 \\
\hline Sore: Docque
\end{tabular}

Source: Docquier and Machado (2015).

\footnotetext{
${ }^{16}$ The model is calibrated to the world economy in year 2000, whereas the dynamics of the population on to the period 1975-2000. The baseline scenario is consistent with the "High Fertility" projection of the Unites States. For further details please refer to Docquier and Machado (2015).
} 
Immigration rates from the baseline scenario are reported in Table 8. Assuming long-run convergence in TFP, between emerging and high income countries the baseline projection shows a relatively modest increase in worldwide migration flows over the $21^{\text {st }}$ century, i.e. the proportion of adult migrants will increase from 3.5 to 4.5 percent of the labor force.

However, giving the current policy framework, the migration pressure toward the European Union (EU) will increase significantly, from 7.5 to 17.2 percent, in particular from Africa to Western Europe countries. Noteworthy, fertility and human capital investments show a prominent role as drivers of international migration flows to EU. A partial convergence in TFP or a reduction in birth rates in African countries is expected to diminish long-run immigration rates in Europe by 3 percentage points.

\section{World Trade patterns}

Fontagné and Fouré (2015) take a 2035 horizon and examine how world trade patterns will react to reshaping comparative advantages and capabilities of different regions, and provide the allocation value added across sectors and countries. Their analysis proceeds in three steps. The first step make use of a convergence model (i.e. MaGE) including three production factors (capital, labour and energy) and two factor-specific productivities in order to derive economic growth paths, under specific hypotheses on fertility, migrations ${ }^{17}$, educational convergence, TFP, energy price ${ }^{18}$ energy efficiency and international capital mobility.

In the second step, growth projections are used as input into a dynamic Computable General Equilibrium (CGE) model (i.e. MIRAGE) of the world economy, calibrated to reproduce observed elasticity of trade to income. The CGE provides sector decomposition of growth, factor allocation, country specialization and world trade patterns ${ }^{19}$. Finally, additional shocks are then imposed on the CGE to evaluate the effects of specific (Trade Policy) shocks on future allocation of value added across countries and sectors.

In detail, two typical macroeconomic trajectories for the world economy can be considered at the 2035 horizon: "Sluggish Macro" and "Brisk Macro". These two trajectories are used to calibrate two dynamic trajectories with MIRAGE: "Sluggish Secto" and "Brisk Secto". Finally, are performed two more simulation corresponding to a cooperative world versus a trade war: "brisk and connected" and "sluggish and fragmented" respectively. The detailed assumption for each scenario and step are reported in Table 9.

Regarding migration flows, the initial migrants in UN projections determine the reference case for migrations, applied to the "Sluggish Macro" scenario. In contrast, the "Brisk Macro" scenario includes migrations from Docquier and Machado (2015). Moreover, in the "Sluggish Macro" scenario the convergence in education (which drives TFP convergence) it is assumed to be slower with respect to the "Brisk Macro" (roughly 50\% slower), reducing technological catch-up and finally hampering economic growth.

\footnotetext{
${ }^{17}$ Migration projections are from Docquier and Machado (2015).

${ }^{18}$ From the International Energy Association IEA

19 The first step is performed with a growth model derived theoretically (MaGE) used to make macroeconomic projections for more than 160 countries. The second step involves the calibration of the dynamic trajectory of CGE model such that it matches the first step projections (i.e. GDP growth projection and energy prices) under sectorspecific constraints, current account constraints and exogenous agricultural productivity (MIRAGE model). For further details on the two models and the estimation workflow please refer to Fontagné and Fouré (2015).
} 
Table 9: The two scenarios

\begin{tabular}{|c|c|c|c|}
\hline \multicolumn{4}{|c|}{ REFERENCE } \\
\hline \multirow{8}{*}{ MaGE } & & Sluggish Macro & Brisk Macro \\
\hline & Demography & Low fertility for all countries & High fertility in all countries \\
\hline & Migrations & Reference case & Docquier (baseline) \\
\hline & $\begin{array}{l}\text { Education } \\
\text { convergence }\end{array}$ & $+50 \%$ half-life time & $\begin{array}{l}\text { Reference case }+ \text { Migration from } \\
\text { Docquier }\end{array}$ \\
\hline & $\begin{array}{l}\text { Differentiated } \\
\text { TFP }\end{array}$ & $\begin{array}{l}-50 \% \text { TFP growth rate for low and } \\
\text { mid income countries, }-25 \% \text { for } \\
\text { high-income. }\end{array}$ & Reference case \\
\hline & Oil price & High price scenario (IEA) & Low price scenario (IEA) \\
\hline & $\begin{array}{l}\text { Energy } \\
\text { productivity }\end{array}$ & $+25 \%$ targeted in 2050 & Reference case \\
\hline & Capital mobility & $\begin{array}{l}\text { Convergence to } \mathrm{I}=\mathrm{S} \text { targeted in } \\
2050 \text {, in each region }\end{array}$ & Reference case \\
\hline \multirow{5}{*}{ MIRAGE } & & Sluggish Secto & Brisk Secto \\
\hline & Energy prices & High price scenario (IEA) & Low price scenario (IEA) \\
\hline & Transaction costs* & $25 \%$ cut & $25 \%$ cut \\
\hline & Transport TFP* & $2 \%$ annual growth & $2 \%$ annual growth \\
\hline & Tariffs & No change (w.r.t. 2011) & No change (w.r.t.2011) \\
\hline \multicolumn{4}{|c|}{ SIMULATION } \\
\hline \multirow{5}{*}{ MIRAGE } & & Sluggish \& Fragmented & Brisk \& Connected \\
\hline & NTM in services & No change & $-25 \%$ \\
\hline & Transaction costs & $+50 \%$ from developing countries & $-50 \%$ developing countries \\
\hline & for goods & $+20 \%$ from developed countries & -20\% developed countries \\
\hline & Tariffs on goods & Trade war (Tokyo round tariffs) & $-50 \%$ compared to 2010 \\
\hline
\end{tabular}

Source: Fontagné and Fouré (2015). *As discussed, the trends were introduced in a pre-experiment in order to reproduce longterm income elasticity of world trade. 
Overall simulation results are depicted in Figure 7, reporting the growth rate of trade and gross domestic products under the "Brisk", "Brisk \& Connected", "Sluggish" and "Sluggish \& Fragmented" scenarios in MIRAGE. Scenarios with no trade policy assumptions ("Brisk" and "Sluggish") are depicted with plain line rectangles, while the two scenarios including trade policies ("Brisk \& Connected" and "Sluggish \& Fragmented”) are shown with different colours.

Under the 'Brisk \& Connected' scenario, exports of goods in developing economies will grow at about 6\% per year (4.5\% in the 'Brisk Secto' scenario). The expected growth is even larger for services, although export figures in value are less impressive for services. In the 'Sluggish \& Fragmented' scenario, GDP grows much slower, in particular for developing countries, while trade costs (tariffs and transaction costs) increases. Sluggish scenarios are particularly penalizing for goods, especially the 'Sluggish \& Fragmented': goods are penalized by both tariff wars and transportation costs, whereas services are only subject to regulations, which are assumed to be invariant under the Sluggish scenario. Finally, exports in developing countries' are significantly affected by the combined effect of transaction costs, tariff and growth assumptions under the Sluggish scenario.

Table 10 provides information on the distribution of value added at the (macro) sector and country level issued from the simulation exercise. Not surprisingly the European share of world value added is expected to decrease, mainly as a result of the development of emerging countries. Interestingly, this reduction is highly heterogeneous across both sectors and scenarios. For the manufacturing sector, the value added records a 3.6 percentage point decrease in the 'Brisk \& Connected' scenario, while only recording a 2.4 p.p. reduction in the 'Sluggish \& Fragmented' scenario, mainly due to the fact that developing economies are expected to perform relatively worse than developed countries. On the contrary, in the Services sectors, the contraction in value added shares is greater (-6.8 p.p.) and not significantly different across the different scenarios. However, it is interesting to note that in any case value-added is expected to more than double between 2011 and 2035.

The second result is about individual EU Member states. The share of Germany, Italy and France in the European manufacturing value added is expected to shrink in both scenarios, whereas is expected to remain relatively stable for Spain or even increasing for the United Kingdom. This evolution is offset by a 13.4 percentage point increase in the share of the manufacturing value added of "Other EU28" members, suggesting a significant reallocation of economic activity away from Germany, Italy or France towards the New Member states. Regional production chains could be much more fractioned than they are today, and manufacturing as a whole could well further go East. It is worth stressing, that such reallocation does not imply a reduction in absolute terms of the German value added in manufacturing (which is actually expected to increase under both scenarios), but that most of the growth in the manufacturing value added would take place outside the country boundaries. In simple words, existing plants will hardly be closed in the most competitive historical Member states, but the new plants will be located in the New member states predominantly. 
Figure 7: GDP (volume) and exports (volume, incl. intra) growth rates, 2012-2035

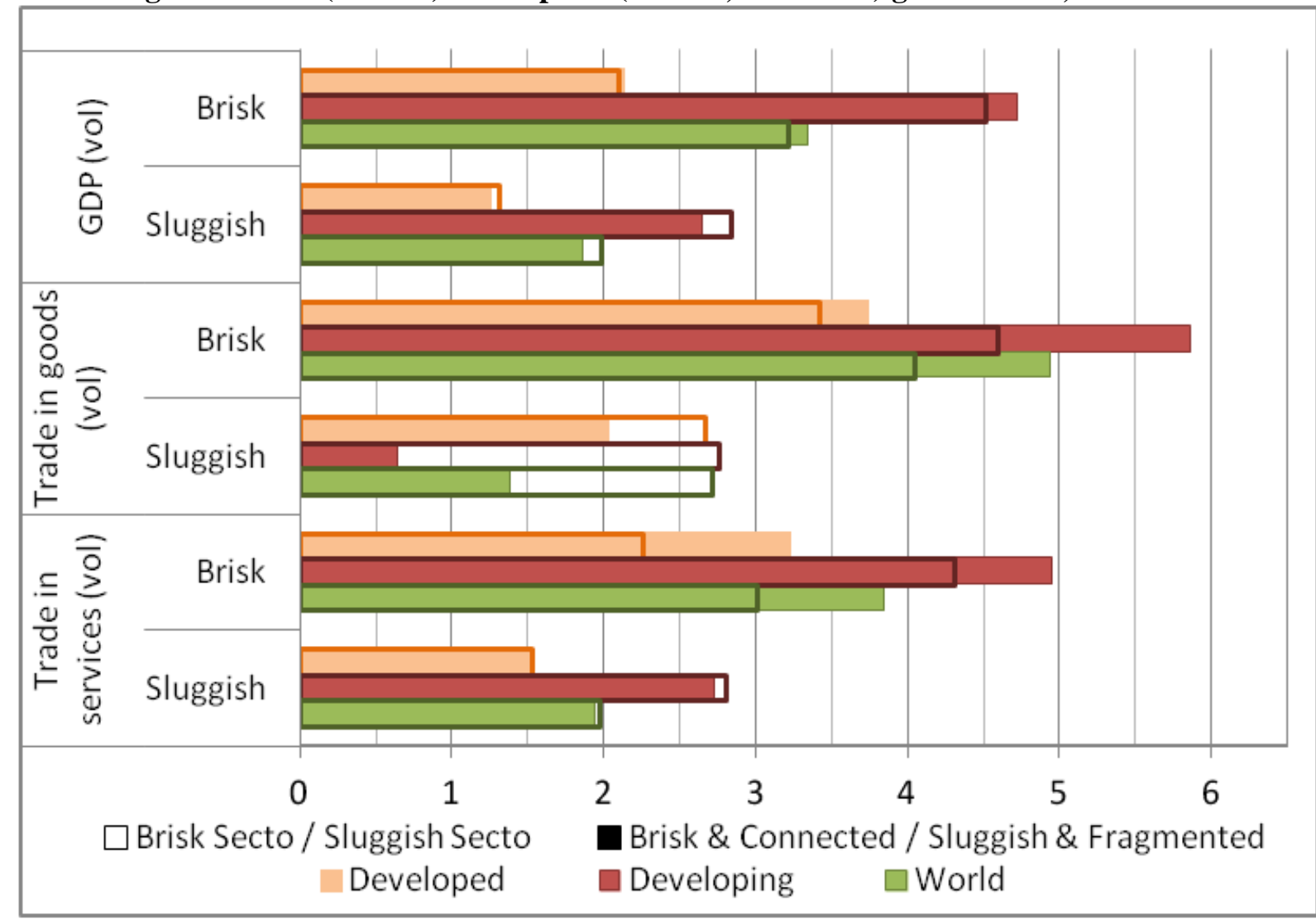

Source: Fontagné and Fouré (2015).Note: average annual growth rates (percentages). For Developing countries trade in services is expected to grow at $4.5 \%$ per year in the 'Brisk Secto' scenario, compared to 5.5\% under the 'Brisk \& Connected' scenario. 
Table 10: Value-added in the EU (volume): Total value-added, share in the world and distribution inside EU, 2013 and 2035

\begin{tabular}{|c|c|c|c|c|c|c|c|c|c|c|}
\hline & & \multicolumn{3}{|c|}{ Primary } & \multicolumn{3}{|c|}{ Manufacturing } & \multicolumn{3}{|c|}{ Services } \\
\hline & & 2011 & $\begin{array}{c}\text { Sluggish } \\
\text { Fragmented } \\
(2035)\end{array}$ & $\begin{array}{c}\text { Brisk } \\
\text { Connected } \\
(2035) \\
\end{array}$ & 2011 & $\begin{array}{c}\text { Sluggish } \\
\text { Fragmented } \\
(2035)\end{array}$ & $\begin{array}{c}\text { Brisk } \\
\text { Connected } \\
(2035) \\
\end{array}$ & 2011 & $\begin{array}{c}\text { Sluggish } \\
\text { Fragmented } \\
(2035)\end{array}$ & $\begin{array}{c}\text { Brisk } \\
\text { Connected } \\
(2035) \\
\end{array}$ \\
\hline \multirow{2}{*}{$\begin{array}{l}\text { European } \\
\text { Union }\end{array}$} & Total (billion 2007 USD) & 188 & 460 & 542 & 1236 & 3005 & 3200 & 4975 & 13310 & 15576 \\
\hline & Share in the world (\%) & 5.6 & 5.8 & 6.0 & 22.3 & 19.9 & 18.7 & 27.2 & 20.4 & 20.6 \\
\hline \multirow{6}{*}{$\begin{array}{l}\text { Shares } \\
\text { EU (\%) }\end{array}$} & France & 9.1 & 10.1 & 11.3 & 15.1 & 10.1 & 11.3 & 15.1 & 16.9 & 16.8 \\
\hline & Germany & 10.4 & 12.7 & 12.8 & 20.5 & 12.7 & 12.8 & 20.5 & 16.6 & 16.5 \\
\hline & Italy & 7.6 & 9.6 & 10.4 & 15.0 & 9.6 & 10.4 & 15.0 & 8.7 & 9.0 \\
\hline & Spain & 6.9 & 8.8 & 8.0 & 8.8 & 8.8 & 8.0 & 8.8 & 8.3 & 8.2 \\
\hline & United Kingdom & 24.3 & 17.7 & 16.8 & 12.8 & 17.7 & 16.8 & 12.8 & 18.7 & 18.8 \\
\hline & Other EU28 & 41.8 & 41.2 & 40.7 & 27.8 & 41.2 & 40.7 & 27.8 & 30.8 & 30.8 \\
\hline \multirow{6}{*}{$\begin{array}{l}\text { Shares in } \\
\text { national } \\
\text { economy } \\
(\%)\end{array}$} & France & 1.8 & 1.7 & 1.9 & 17.9 & 17.0 & 15.8 & 80.2 & 81.3 & 82.3 \\
\hline & Germany & 1.5 & 2.1 & 2.1 & 17.7 & 19.4 & 18.9 & 80.8 & 78.5 & 79.0 \\
\hline & Italy & 1.5 & 2.9 & 3.1 & 19.2 & 21.9 & 20.7 & 79.3 & 75.2 & 76.2 \\
\hline & Spain & 2.4 & 3.0 & 2.9 & 17.4 & 14.7 & 13.3 & 80.2 & 82.3 & 83.8 \\
\hline & United Kingdom & 5.9 & 2.7 & 2.6 & 12.0 & 15.1 & 13.9 & 82.2 & 82.2 & 83.5 \\
\hline & Other EU28 & 4.0 & 3.6 & 3.7 & 24.6 & 18.8 & 16.9 & 71.4 & 77.6 & 79.5 \\
\hline
\end{tabular}

Source: Fontagné and Fouré (2015). 


\section{Macroeconomic effects of energy prices}

The impact of energy prices on the world economy evolution, factor allocation and trade in the 2035 horizon is addressed in Fontagné et al. (2015). The analysis focus on a specific projection from the Computable General Equilibrium model, MIRAGE, issued after imposing alternative trajectories for energy prices (high, medium and low prices) and details the consequence for country specialization and factor allocation across European Union countries and sectors.

Several factors can increase uncertainty on future energy prices, including technological improvement in production and energy efficiency as well as geopolitical tensions. Looking at the evolution of energy prices in the medium/long term is particularly important, since their developments can have significant consequences for growth trajectory of world economies ${ }^{23}$.

Moreover, taking the trajectory for key energy fossil fuels (oil, coal and natural gas) Fontagné et al. further illustrate the links between resource scarcity and climate change by simulating the effect of environmental policies, based on the Copenhagen agreement pledges in 2009, on economic growth.

Table 11: Macroeconomic Setup under different energy price trajectories

\begin{tabular}{|c|c|c|c|c|}
\hline & & $\begin{array}{l}\text { Scarce } \\
\text { resources } \\
\text { BAU }\end{array}$ & $\begin{array}{c}\text { Medium } \\
\text { resources } \\
\text { BAU }\end{array}$ & $\begin{array}{c}\text { Abundant } \\
\text { Resources } \\
\text { BAU }\end{array}$ \\
\hline MaGE & Oil price & High price scenario (IEA) & Medium price scenario (IEA) & $\begin{array}{c}\text { Low price scenario } \\
\text { (IEA) }\end{array}$ \\
\hline \multirow{4}{*}{ MIRAGE } & Energy prices & $\begin{array}{c}\text { High price scenario } \\
\text { (IEA) }\end{array}$ & Medium price scenario (IEA) & $\begin{array}{c}\text { Low price scenario } \\
\text { (IEA) }\end{array}$ \\
\hline & $\begin{array}{l}\text { Transaction } \\
\text { costs }\end{array}$ & $25 \%$ cut & $25 \%$ cut & $25 \%$ cut \\
\hline & $\begin{array}{c}\text { Transport } \\
\text { TFP }\end{array}$ & $2 \%$ annual growth & $2 \%$ annual growth & $2 \%$ annual growth \\
\hline & Tariffs & $\begin{array}{l}\text { No change } \\
\text { (w.r.t. 2011) }\end{array}$ & $\begin{array}{l}\text { No change } \\
\text { (w.r.t. 2011) }\end{array}$ & $\begin{array}{l}\text { No change } \\
\text { (w.r.t. 2011) }\end{array}$ \\
\hline
\end{tabular}

Source: Fontagné et al. (2015). Note: Setup for the macroeconomic model (MaGE) and the CGE model (MIRAGE). Energy prices, reflecting the abundance/scarcity of resources, are from the IEA (2015) projections. The "Business-As-Usual” (BAU) scenario implies no changes in the current environmental policy framework.

Consistently with Fontagné and Fouré (2015) the workflow consists in two main steps: the "Macro" generating economic growth projections by country (performed with MaGE); the "Secto" step producing resource allocation and dynamic trajectory that match the Macro projections (performed with MIRAGE). Table 11 reports the detailed setup for both the Macro and Secto step. Noteworthy, the proposed scenarios differ only in terms of natural resource scarcity, which in turn drive the allocation of economic activity in the three simulations.

\footnotetext{
${ }^{23}$ Price trajectories are taken from the International Energy Agency (Outlook 2015). In particular energy prices are modelled as supply side shocks increasing (reducing) product scarcity. For further details on the other assumptions please refer to Fontagné and Fouré (2015) and Fontagné et al. (2015).
} 
Finally, the CGE is mobilized in a third step to build alternative scenarios of the world economy that take into account environmental policy changes (Copenhagen pledges). For sake of clarity, the environmental scenarios are named "CO2" whereas the corresponding baselines are named "BAU" (business-as-usual).

The results of the two scenarios ('business-as-usual' and 'CO2') simulated in MIRAGE, are reported in Figure 8. Simulations confirm that whatever be the availability of natural resources, world CO2 emissions are likely to more than double within the next 20 years, up to over 60 thousand $\mathrm{MtCO}_{2}$ from less than 30 thousand in 2011. However, the effectiveness of emissions reductions policies appears to be sensitive to the level of natural resource scarcity. Climate policy outcomes under abundant resources, in fact, are only marginally below the level of emissions that could be achieved under the current climate policy (BAU) and a relatively high level of energy prices (scarce resources).

The economic cost of Copenhagen pledges under different scenarios for energy prices is summarized in Table 12. Two effects are occurring in parallel. First, the economic cost of adjustment to Copenhagen commitments is increasing in the constraint level (high constrain leads to higher costs of adjustment). Second there is evidence of an energy market effect in Russia, Middle-East countries and Sub-Saharan Africa: a high constraint in the world lead to a drop in demand for fuel, implying greater losses for energy producing countries. In general, within pledging countries, the lower the constraint, the even lower the cost, interestingly some countries even experience an increase in GDP, due to the "free-rider" effect (USA, ASEAN).

Figure 8: World CO2 emissions by fuel, 2011 and 2035 under alternative scenarios, $\mathrm{MtCO}_{2}$

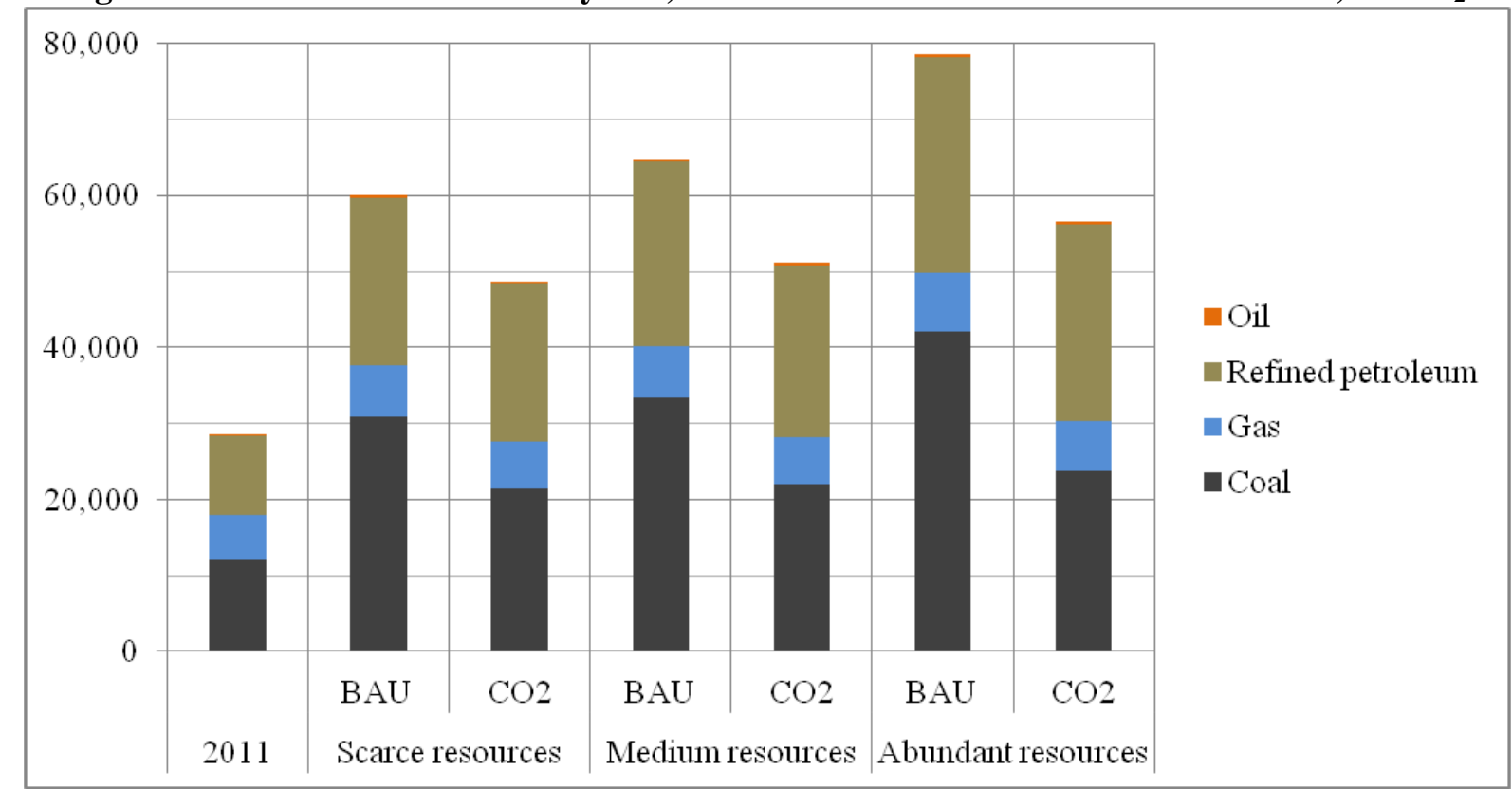

Source: Fontagné et al. (2015). Note: In metric tons of carbon dioxide equivalent (MtCO2). 
Table 12: Variation in 2035 GDP due to Copenhagen pledges under alternative scenarios

\begin{tabular}{lccc}
\hline & $\begin{array}{c}\text { Scarce } \\
\text { resources }\end{array}$ & $\begin{array}{c}\text { Medium } \\
\text { resources }\end{array}$ & $\begin{array}{c}\text { Abundant } \\
\text { resources }\end{array}$ \\
\hline Russia & -1.92 & -2.06 & -2.48 \\
Other Middle East & -1.45 & -1.76 & -2.49 \\
Japan & -1.67 & -1.74 & -1.81 \\
Australia \& New Zealand & -0.88 & -0.96 & -1.22 \\
India & -0.74 & -0.95 & -1.87 \\
Mexico & -0.72 & -0.79 & -1.04 \\
China & -0.63 & -0.71 & -0.97 \\
South Africa & -0.47 & -0.51 & -0.66 \\
Korea & -0.57 & -0.49 & -0.18 \\
Sub-Saharan Africa & -0.35 & -0.46 & -0.80 \\
Brazil & -0.46 & -0.42 & -0.34 \\
Spain & -0.17 & -0.22 & -0.27 \\
Other EU28 & -0.14 & -0.19 & -0.26 \\
Canada & -0.14 & -0.17 & -0.27 \\
Italy & -0.13 & -0.16 & -0.18 \\
United Kingdom & -0.08 & -0.12 & -0.22 \\
Germany & -0.08 & -0.12 & -0.18 \\
North Africa & -0.03 & -0.11 & -0.37 \\
France & -0.04 & -0.06 & -0.07 \\
USA & 0.01 & 0.01 & 0.02 \\
ASEAN & 0.06 & 0.03 & -0.21 \\
Rest of the World & 0.11 & -0.07 \\
Turkey & 0.40 & 0.07 & 0.39 \\
\hline World & -0.45 & -0.51 & -0.69 \\
\hline Source: Fontagné et al. (2015) & & & \\
\hline
\end{tabular}




\section{CONCLUSIONS}

This paper addresses recent changes in European competitiveness and the related background in terms of location of the value added. We disentangle composition effects (related to initial product and destination market orientation of exports) from pure competiveness effects, relying on the newly released Measuring Export Competitiveness database. It is shown that most of the recent changes are due to pure competiveness effects rather than composition effects. During the crisis however, export diversification has somehow dampened adverse demand shocks for the most diversified European exporters. Importantly, the growth of Domestic Value Added embodied in Gross Exports has been very uneven across EU member states since the mid-90's. This is the outcome of a profound restructuring of global value chains, whereby new member States have been very dynamic. Such profound reshaping of the European industry has certainly helped salvaging European market shares worldwide.

Starting with a sound assessment of industrial competitiveness of European Member states is important because it will shape the future of the location of value added in Europe. Confronted to structural forces at play in the world economy, as demography, rebalancing of the world GDP towards Asia, or technological catching up of emerging economies, the value added in European economies will be differently affected. Competitive countries (or more plausibly regions, but our study did not have such level of detail) will manage to maintain the share of manufacturing value added in their GDP, notwithstanding sharp reductions in world market shares. These economies will become smaller, but their industries will keep prosperous in a larger world. Germany should be in position to achieve this goal, Italy as well, thanks to a good sectoral orientation of exports and a positive covariance between world trade and country competitiveness effect in the latter case. France and Spain, because they are less competitive, will suffer reinforced deindustrialization and reduced market shares. 


\section{REFERENCES}

Amador J., Cappriello R. and Stehrer R. (2015) “Foreign value added in European exports”, Mimeo.

Baldwin R. and J. Javier Lopez-Gonzalez (2013), "Supply-Chain Trade: A Portrait of Global Patterns and Several Testable Hypotheses", NBER Working Papers 18957, National Bureau of Economic Research, Inc.

Baldwin, R. (2006), "Globalisation: The great unbundling(s)”, contribution to the project Globalisation Challenges for Europe and Finland organised by the Secretariat of the Economic Council.

Baldwin, R. (2012), "Global supply chains: why they emerged, why they matter, and where they are going?”, CEPR Discussion Paper No. 9103, August.

Bricongne J.C., L. Fontagné, G. Gaulier, D. Taglioni and V. Vicard (2012), "Firms and the Global Crisis: French exports in the turmoil”, Journal of International Economics 87, 1 134-146.

Chaney, T. (2008). Distorted gravity: the intensive and extensive margins of international trade. The American Economic Review, 98(4), 1707-1721.

Cheptea A., G. Gaulier and S. Zignago (2005), "World Trade Competitiveness: a Disaggregated View by Shift-Share Analysis”, CEPII Working Paper 23.

Cheptea A., L. Fontagné and S. Zignago (2014), "European Export Performance”, Review of World Economics, 150(1): 25-58.

Corcos G, M. Del Gatto, G. Mion and G.I.P. Ottaviano (2012), "Productivity and Firm Selection: Quantifying the 'New' Gains from Trade", Economic Journal, Royal Economic Society, vol. 122(561), pages 754-798, 06.

Docquier, F. and Machado, J. (2015), “Income disparities, population and migration flows over the $21^{\text {st }}$ century”, Mimeo.

Eaton J., S. Kortum, B. Neiman and J. Romalis (2013), "Trade and the Global Recession", Working Papers 2013-21, University of Sydney, School of Economics.

Escaith H, N Lindinberg and S Miroudot (2010), "Global Value Chains and the Crisis: Reshaping Trade Elasticity?”, in Cattaneo O, G Gereffi and C Staritz (eds) (2010), Global Value Chains in a Post crisis World. A Development Perspective. Washington, D.C.: The World Bank, 73-124.

Fontagné L. and J. Fouré (2015), "Value Added in Motion: Modeling World Trade Patterns at the 2035 Horizon”, mimeo.

Fontagné L., J. Fouré and A. Keck (2013b), “Simulating world trade in the decades ahead: Driving forces and policy implications”, WTO Working Paper.

Fontagné L., J. Fouré and G Santoni (2015), "Value Added in Motion: Macroeconomic Implications of Energy Price Trajectories”, mimeo.

Fontagné L., J. Fouré and M. Ramos (2013a), "MIRAGE-e: A General Equilibrium Long-term Path of the World Economy”, CEPII Working paper \#2013-39. 
Fouré J., A. Bénassy-Quéré and L. Fontagné (2013), “Modelling the world economy at the 2050 horizon”, Economics of Transition, 21(4): 617-654.

Fouré, J., A. Bénassy-Quéré and L. Fontagné (2012), “The Great Shift: Macroeconomic Projections for the World Economy at the 2050 Horizon”, CEPII Working paper 2012-03.

Fujita M. (2013), “The lessons from the Great East Japan Earthquake and the Great Floods in Thailand”, Vox EU, 18 November.

Gaulier G., G. Santoni, D. Taglioni and S. Zignago (2013), "In the wake of the global crisis: evidence from a new quarterly database of export competitiveness", Policy Research Working Paper Series 6733, The World Bank.

Gaulier G., G. Santoni, D. Taglioni and S. Zignago (2015), "The power of the few in determining trade accelerations and slowdowns ", mimeo.

Gopinath G., O. Itskhoki and B. Neiman (2012), "Trade Prices and the Global Trade Collapse of 20082009", CEPR Discussion Papers 9158, C.E.P.R. Discussion Papers.

Hoekman B. (2014), "Supply Chains, Mega-Regionals and Multilateralism: A Road Map for the WTO", RSCAS Working Papers 2014/27, European University Institute.

Johnson, R. C., and Noguera, G. (2012), "Proximity and Production Fragmentation," American Economic Review, American Economic Association, vol. 102(3), pages 407-11, May.

Kee H.L. and Tang H. (2012), "Domestic Value Added in Chinese Exports", February, mimeo

Koopman R., W. Powers, Z. Wang and S.J. Wei (2011), "Give Credit where Credit is Due: Tracing Value Added in Global Production Chains", Working Papers 312011, Hong Kong Institute for Monetary Research.

Koopman R., Z. Wang and S.J. Wei (2012), "Estimating Domestic Content in Exports when Processing Trade is Pervasive", Journal of Development Economics, vol.99(1), pages 178-189, January.

Lamy P. (2013), “Global value chains, interdependence, and the future of trade”, Vox EU, 18 December.

Lemoine F., G. Mayo, S. Poncet and D. Ünal (2014), "The Geographic Pattern of China's Growth and Convergence within Industry", CEPII Research Center, Working Papers No.4, March.

Melitz M. (2003), "The Impact of Trade on Intra-Industry Reallocations and Aggregate Industry Productivity", Econometrica, Econometric Society, vol. 71(6), pages 1695-1725, November.

Melitz M. and G. I. P. Ottaviano (2008), "Market size, trade and productivity”, Review of Economic Studies, 75, 295-316.

Ottaviano G., D. Taglioni and F. Di Mauro (2009), "The Euro and the Competitiveness of European Firms”, Economic Policy.

Santoni G. and Taglioni D. (2015), "Networks and structural integration in Global Value Chains", in Amador J. and di Mauro F. (Ed), The Age of Global Value Chains: Maps and Policy Issues, CEPR Ebook. 
Taglioni D. and D. Winkler (2014), "Making Global Value Chains Work for Development", World Bank Economic Premise, The World Bank, issue 143, pages 1-10, May.

Taglioni D. and D. Winkler (2015), "Making Global Value Chains Work for Development", World Bank. Wooldridge, J. M. (2010), “Econometric analysis of cross section and panel data”, MIT press. 


\section{APPENDiXES}

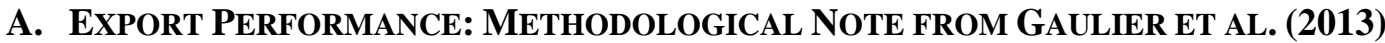

The empirical analysis carried out to decompose country export performance involves four main steps:

Step 1: Computation of Mid-Point Growth Rates (dependent variable)

Export growth rates are computed as Year-on-Year quarterly changes to control for seasonality. For country $\mathrm{i}$ the 2006q1 ( $t$ ) growth rate is computed as the change of exports with respect to 2005q1 (t-1). For a country $i$ exporting a value $x$ to a country $c$ of product $k$ at time $t$, the mid-point growth rate is defined as follows:

Equation 1: $\quad g_{i c k t}=\frac{x_{i c k t}-x_{i c k(t-1)}}{\frac{1}{2}\left(x_{i c k t}+x_{i c k(t-1)}\right)}$

Note that this is the building block of the export decomposition. To each elementary flow is attributed a weight given by the relative share of the flow in total exports, i.e. the aggregate exports of the full set of countries in the sample (may be slightly different from world exports):

Equation 2:

$$
S_{i c k t}=\frac{x_{i c k t}+x_{i c k(t-1)}}{\left(\sum_{c} \sum_{i} \sum_{k} x_{i c k t}+\sum_{c} \sum_{i} \sum_{k} x_{i c k(t-1)}\right)}
$$

The main advantage of using Equation (1) and Equation (2) in defining country export growth rates is that in this way we are able to account for the extensive margin of trade: when a new trade flow appears in the data the mid-point growth rate, $g_{i c k t}$ is equal to +2 ; in the same fashion when a trade flow disappears $g_{\text {ickt }}$ is equal to -2 .

The year-on-year growth rate of the total value of world exports is given by summing each individual flow $g_{i c k t}$ weighted by $s_{i c k t}$.

Equation 3: $\quad G_{t}=\sum_{c} \sum_{i} \sum_{k} s_{i c k t} * g_{i c k t}$

The $\mathrm{G}$ measure is very good approximation of the true percentage change, except for extremely high growth rates. For bigger growth rates the two measures are linked by the identity:

Equation 4: $\quad G_{i}=\sum_{c, k} g_{i c k} * s_{i c k} \approx \ln \left(\frac{\sum_{c, k} x_{i c k}^{t}}{\sum_{c, k} x_{i c k}^{t-1}}\right)$

For a country i the aggregate mid-point growth rate approximate the change in logarithm ${ }^{24}$. The difference between $\mathrm{G}$ and true percentage changes at the country level is relatively small when a country reports

24 Strictly speaking, the percentage change in a variable $\mathrm{X}$ at period $\mathrm{t}$ is defined as $(\mathrm{X}(\mathrm{t})-\mathrm{X}(\mathrm{t}-1)) / \mathrm{X}(\mathrm{t}-1)$, which is approximately equal to $\operatorname{LOG}(\mathrm{X}(\mathrm{t}))$ - $\operatorname{LOG}(\mathrm{X}(\mathrm{t}-1))$. The approximation is almost exact if the percentage change is small. For example, a 5\% percentage change in delta logs is equal to $4.88 \%$, i.e. $\ln (1+5 \%)=0.0488$. 
more than 10000 elementary flows by period. Tanking the example of Pakistan the difference between conventional and weighted mi-point growth rate is $0.05 \%$ - for an average growth rate of $-10 \%$ between 2008q4-2009q4. Of course such discrepancies are higher for less diversified countries (with fewer elementary flows). In 2009q1 Trinidad and Tobago reported aggregate exports 90\% higher than the previous quarter, the corresponding aggregate mid-point growth rate (weighted average of mid-point growth rate over all exports flows reported) is $86 \%$. The same quarter Iceland reported a $38.5 \%$ drop in exports, which is pretty well approximated by the mid-point growth rate at $-38 \%$.

Step 2: Fixed effects regression

Our main variable of interest is $g_{i c k t}$. We use the ANOVA methodology to decompose export growth in a sectoral effect, a geographical effect and a pure competitiveness effect. Essentially we decompose the variance of $g_{i c k t}$ into the three main components: i (exporter), c (importer), k (sector).

In order to perform the decomposition we regress the mid-point growth rate on a set exporter, importer and product fixed effects (f) by means of a weighted OLS estimation according to Equation 5 . At time $t$ each observation is weighted by $s_{i c k}$. The estimation is performend separately for each period t.

\section{Equation 5: $\quad g_{i c k}=\sum_{i} \phi_{i} f_{i}+\sum_{c} \beta_{c} f_{c}+\sum_{k} \gamma_{k} f_{k}+\varepsilon_{i c k}$}

The terms $f_{i}, f_{c}$ and $f_{k}$ are the exporter country, importer country and product specific fixed effects (dummy variables). From Equation 5 we obtain the estimated coefficients $\hat{\phi}_{i}, \hat{\beta}_{c}$ and $\hat{\gamma}_{k}$ that we further normalize in order to obtain our final indicators.

Step 3: Computation of the indices from the estimated coefficients

In Equation 6, $\mu_{i}$ gives the export growth that country i would have if its geographical and sectoral specialization would be equal to the average for the full sample: average destination markets effect $\sum_{c} s_{i c} \hat{\beta}_{c}$ and average product effect $\sum_{k} s_{i k} \hat{\gamma}_{k}$. It can be seen as a counterfactual: what would have been the export growth of country $\mathrm{i}$ if the country had the same product and geographical specialization as a representative country (sample average) ${ }^{25}$.

\section{Equation $6 \quad \mu_{i}=\hat{\phi}_{i}+\sum_{c} s_{i c}^{t} \hat{\beta}_{c}+\sum_{k} s_{i k}^{t} \hat{\gamma}_{k}$}

This allows writing down the identity in Equation 7. The equality exploits the fact that the weights of all flows involving exporter i sum to the weight of its exports in world trade, i.e. $s_{i}=\sum_{c k} s_{i, c, k}$ and that the sample weighted average error in Equation 5 is zero.

25 Specifically, to obtain such term, we need to carry out a least-squares means computation. In other words, for each exporter i, we need to normalize coefficients for the fixed effects, by summing them up to a constant term equal for all i's and to the weighted mean of the partner and product effects (weights are selected and computed using the methodology in Equation 2). This method generates identical results regardless of the choice of the omitted term in the estimation procedure, thereby facilitating interpretation. 
Equation 7:

$$
\begin{gathered}
\ln \left(\frac{\sum_{c, k} x_{i c k}^{t}}{\sum_{c, k} x_{i c k}^{t-1}}\right) \approx \sum_{c, k} G_{i c k}=\sum_{c, k} g_{i c k} * s_{i c k}= \\
\underbrace{\mu_{i}}_{\text {Country Effect }}+\underbrace{\sum_{c} s_{i c} \tilde{\beta}_{c}}_{\text {Destination Effect }}+\underbrace{\sum_{k} s_{i k} \tilde{\gamma}_{k}}_{\text {Product Effect }}
\end{gathered}
$$

Where $\mu_{i}$ is a measure of export performance and $\tilde{\beta}_{c}$ and $\tilde{\gamma}_{k}$ are weighted averages of geographical and sectoral specialization. Intuitively they represent the contribution of the geographical and sectoral composition to the overall export growth for country i. They consider only the specific destinations (c) and products (k) actually served by country i. It is important to note that Equation 7 is an identity. The sum of the three components: exporter competitiveness (country effect), destination market composition and sectoral specialization gives exactly the mid-point growth export growth rate for country i. The Change in market share is defined as the difference between the World and country i mid-point growth rate in period t. Once we re-express country growth rate with respect to the world value all the effects three effect sum to the change in market share they have the same interpretation as before but now they are related to relative export growth.

\section{B. Global Value Chains: Concepts, Measures and Data Sources}

The core concept of GVC trade is 'importing to export' or I2E using Baldwin and Lopez-Gonzales (2013) definition. Basically it refers to the imports of intermediates that are incorporated in country exports. This unique flow carries a great deal of information. From selling country perspective: it indicates that domestic firms are selling inputs to a GVC. From sourcing country perspective: it informs that the domestic exporters are buying inputs from a GVC. Figure A.1 reports the different buyer and seller functions reported by Taglioni and Winkler (2015).

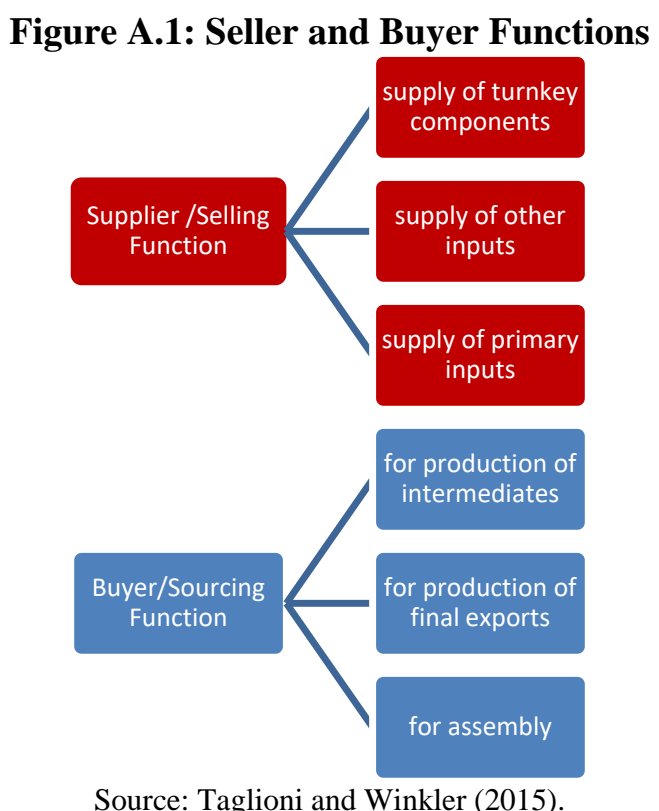

To decompose gross export we follow the approach of Koopmans et al. (2011) stylized in Figure A.2. The first-step is to distinguish between domestic and foreign value added, the second-step looks closer into 
where the domestic value added is incorporated. The second-step divides the domestic contribution into three elements: value added from the same sector as the final product (autos, in the example); value added from other sectors (domestic input supplier) and value added in intermediates first shipped abroad for further processing and then re-imported.

\section{Figure A.2: Decomposition of gross exports: concepts}

$\$ 100$ car industry production

Domestic vs. foreign

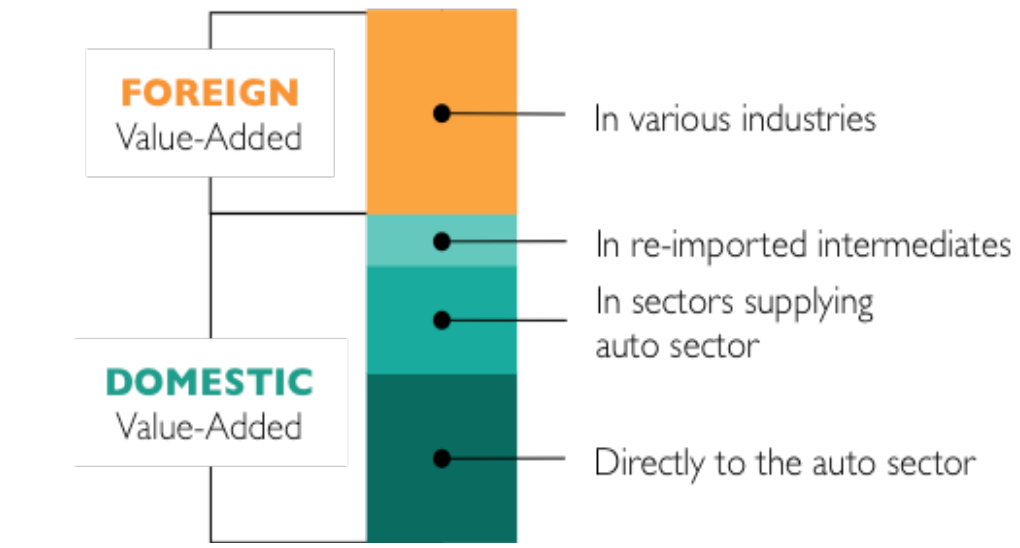

Source: Taglioni and Winkler (2015) based on Baldwin and Lopez-Gonzales (2013).

The decomposition of gross export by value added contribution requires specific statistics on value added cross-country flows, nowadays several database are available: OECD-WTO Trade in Value Added (TiVA), World Input-Output Database (WIOD) of an 11-institution consortium, the UNCTAD-Eora GVC database, and the forthcoming World Bank Export of Value Added database based on the Global Trade Analysis Project database26.

26 TiVA and WIOD allow a full decomposition of value added by source country and industry, and by destination country and industry. The first database covers 58 economies and 37 industries for intermittent years $(1995,2000$, 2005, 2008, and 2009). The second covers the $27 \mathrm{EU}$ members and 13 other major economies, plus an aggregate for the rest of the world. It covers 35 industries and all years from 1995 to 2009. The World Bank Export of Value Added database cover 57 sectors in 100 countries for intermittent years between 1992 and 2010 (based on GTAP social accounting matrices). Eora global multiregional I-O (MRIO) tables uses various data sources combined through interpolation and estimation techniques to provide contiguous datasets. 


\section{Global VALUe Chains: ADDITIONAL EVIDENCE}

Figure A.3: Foreign Value Added Embodied in Gross Exports (\% Gross Exports)

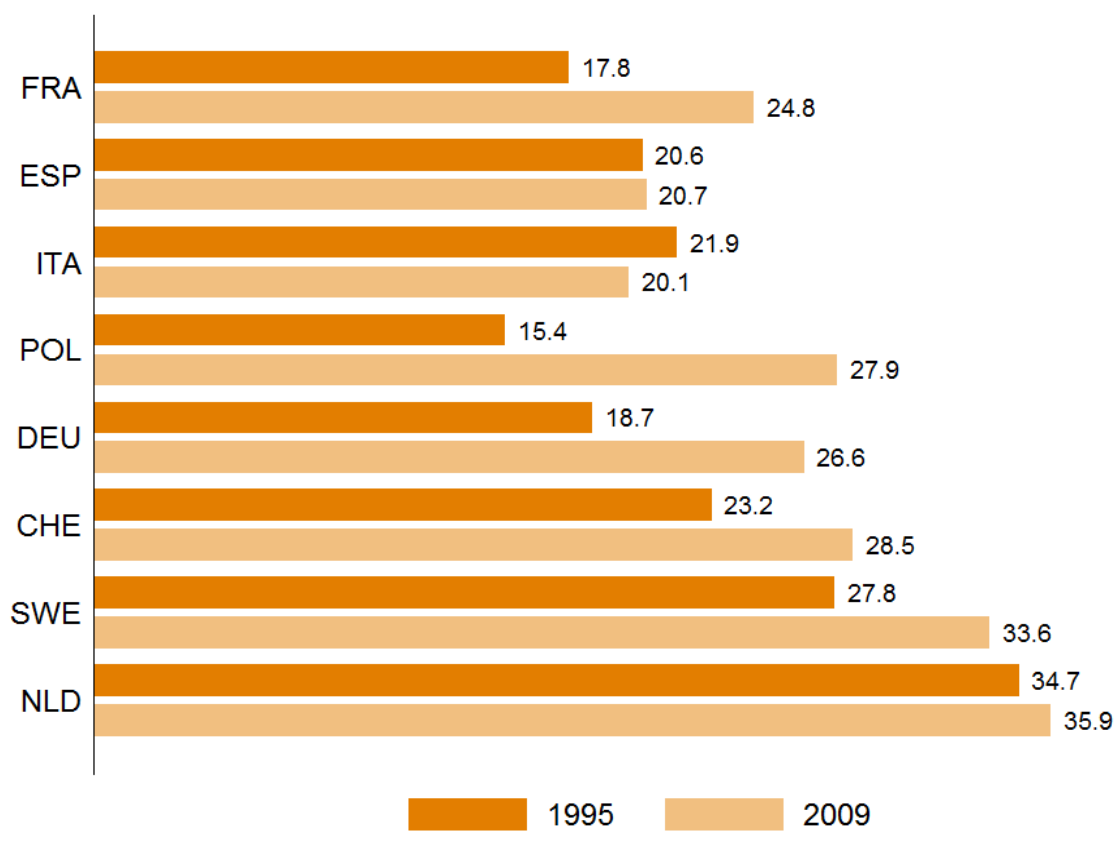

Source: Own calculation on data OECD TiVA. 
Figure A.4: Sourcing and Selling pattern, Italy, year 2009 (total economy)

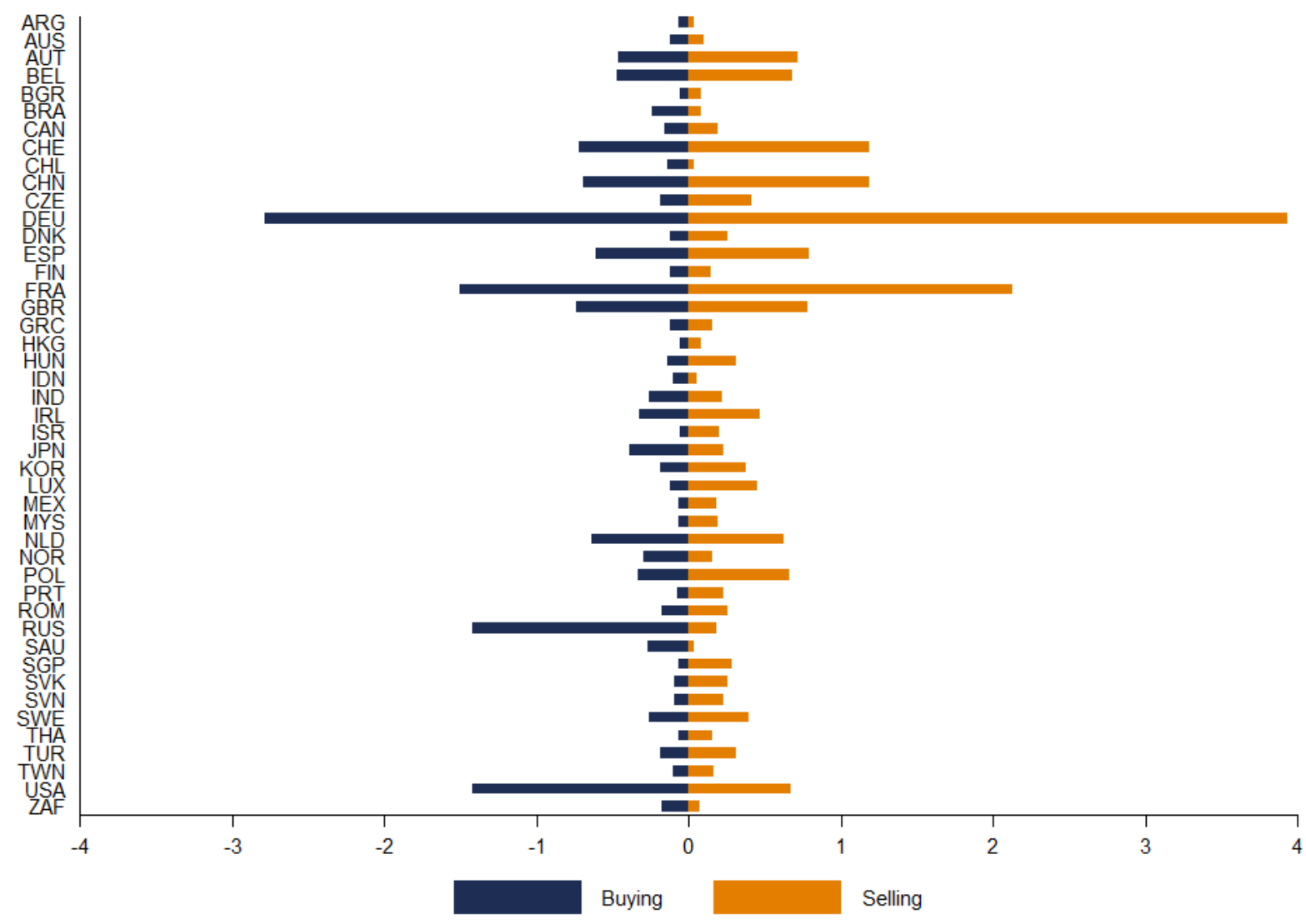

Source: Own calculation on data OECD TiVA. Buying side values needs to be read as positive shares. 
Figure A.5: Sourcing and Selling pattern, Spain, year 2009 (total economy)

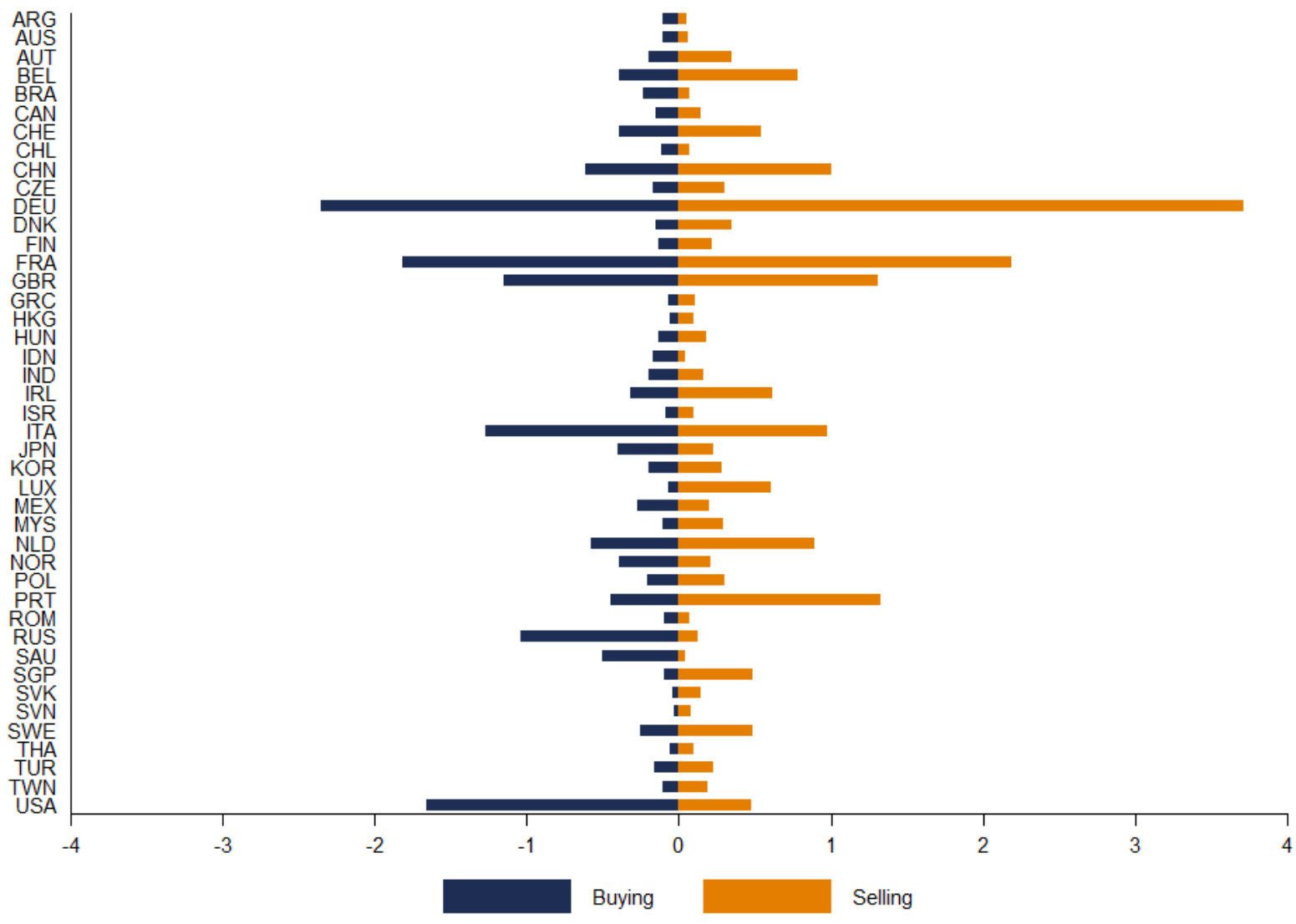

Source: Own calculation on data OECD TiVA. Buying side values needs to be read as positive shares. 